\title{
Autophagy as a Therapeutic Target of Natural Products Enhancing Embryo Implantation
}

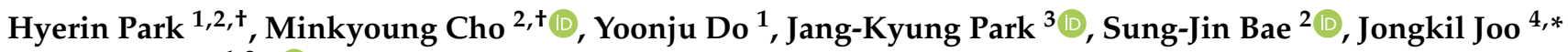 \\ and Ki-Tae Ha $1,2, *$ (D)
}

Citation: Park, H.; Cho, M.; Do, Y.; Park, J.-K.; Bae, S.-J.; Joo, J.; Ha, K.-T. Autophagy as a Therapeutic Target of Natural Products Enhancing Embryo Implantation. Pharmaceuticals 2022 15, 53. https://doi.org/10.3390/ ph15010053

Academic Editors: Sabesan

Yoganathan and Thomas Efferth

Received: 1 November 2021

Accepted: 30 December 2021

Published: 31 December 2021

Publisher's Note: MDPI stays neutral with regard to jurisdictional claims in published maps and institutional affiliations.

Copyright: (C) 2021 by the authors. Licensee MDPI, Basel, Switzerland. This article is an open access article distributed under the terms and conditions of the Creative Commons Attribution (CC BY) license (https:// creativecommons.org/licenses/by/ $4.0 /)$.
1 Department of Korean Medical Science, School of Korean Medicine, Yangsan 50612, Korea; rin8998@pusan.ac.kr (H.P.); uk0243@pusan.ac.kr (Y.D.)

2 Korean Medical Research Center for Healthy Aging, Pusan National University, Yangsan 50612, Korea; letloves1@pusan.ac.kr (M.C.); Dr.NowOrNever@outlook.com (S.-J.B.)

3 Department of Korean Medicine Obstetrics and Gynecology, Pusan National University Korean Medicine Hospital, Yangsan 50612, Korea; vivat314@pusan.ac.kr

4 Department of Obstetrics and Gynecology, Pusan National University Hospital, Busan 49241, Korea

* Correspondence: jkjoo@pusan.ac.kr (J.J.); hagis@pusan.ac.kr (K.-T.H.)

$\dagger$ These authors contributed equally to this study.

\begin{abstract}
Infertility is an emerging health issue worldwide, and female infertility is intimately associated with embryo implantation failure. Embryo implantation is an essential process during the initiation of prenatal development. Recent studies have strongly suggested that autophagy in the endometrium is the most important factor for successful embryo implantation. In addition, several studies have reported the effects of various natural products on infertility improvement via the regulation of embryo implantation, embryo quality, and endometrial receptivity. However, it is unclear whether natural products can improve embryo implantation ability by regulating endometrial autophagy. Therefore, we performed a literature review of studies on endometrial autophagy, embryo implantation, natural products, and female infertility. Based on the information from these studies, this review suggests a new treatment strategy for female infertility by proposing natural products that have been proven to be safe and effective as endometrial autophagy regulators; additionally, we provide a comprehensive understanding of the relationship between the regulation of endometrial autophagy by natural products and female infertility, with an emphasis on embryo implantation.
\end{abstract}

Keywords: autophagy; embryo implantation; female infertility; natural products

\section{Introduction}

Autophagy is a major pathway for lysosome-mediated degradation and recycling of a wide variety of biological macromolecules, including proteins, carbohydrates, lipids, and nucleic acids [1]. In the late 1950s, electron microscopy studies have contributed to the discovery of autophagy. Christian De Duve recognized a lysosome-dependent cellular process for the degradation of intracellular materials and termed it "autophagy" in 1963 [2]. In the early 1990s, Yoshinori Ohsumi created a new paradigm for understanding autophagy by identifying the essential genes for autophagy in baker's yeast [3,4]. Since this breakthrough, molecular studies on autophagy have been conducted in mammalian cells as well as in yeast, and have fueled major advances in biomedical research [5].

Autophagy is well-established as an important mechanism for maintaining cellular homeostasis, including organelle integrity, stress response, metabolic regulation, protein quality control, and host defense, via the removal or recycling of intracellular molecules $[1,5,6]$. Emphasizing the importance of autophagy, various studies have suggested that defective autophagy contributes to and is a therapeutic target for multiple human diseases, such as asthma, systemic lupus erythematosus, Crohn's disease, Parkinson's disease, and several types of cancer [7-11]. Recent studies have revealed that autophagy also plays a 
fundamental role in male and female infertility by regulating the developmental process of reproductive organs and germ cells [12,13]. In particular, there is a specialized endometrial autophagy process to maintain processes that are vital to endometrial homeostasis, including menstruation, embryo implantation, and decidualization [14,15]. In addition, there is evidence that endometrial autophagy is essential for embryo implantation [16-18].

Embryo implantation is defined as a crucial process for attachment of the blastocyst, which is a properly developed embryo, to a receptive uterus and its implantation into the epithelium. Defective embryo implantation leads to an unsuitable environment for pregnancy, leading to a variety of additional problems, including infertility, subfertility, spontaneous miscarriage, abnormal intrauterine fetal growth, and pre-eclampsia [18,19]. Given the importance of embryo implantation, the regulation of endometrial receptivity is currently considered as one of the primary therapeutic strategies for treating female infertility, particularly repetitive implantation failure $[19,20]$.

For successful embryo implantation, the endometrium must undergo various internal changes to increase receptivity for the embryo, without which embryo implantation will not occur or fail. Previous studies have shown that different synchronized molecular processes mediated by a variety of proteins, including cytokines, growth factors, adhesion molecules, and angiogenic factors, are required to regulate endometrial receptivity [21-23]. These molecular and cellular processes are commonly called endometrial autophagy, and defective endometrial autophagy results in endometrial hyperplasia, endometrial carcinoma, endometriosis, and infertility $[15,24,25]$. Therefore, understanding the role of autophagy in the endometrium holds promise for the development of novel therapeutic strategies for improving endometrial function.

Infertility is an important global public health problem, and the use of natural products to treat infertility has been considered a promising and safe alternative to conventional therapies [26-28]. Natural products are derived from diverse sources, including plants, bacteria, and fungi, and have been used as therapeutic candidates for various diseases, including Alzheimer's disease, asthma, atherosclerosis, cancers, obesity, rheumatoid arthritis, and ulcerative colitis [29-33]. In addition, to better understand the efficacy of natural compounds against infertility and their safety, mechanistic studies are currently being conducted to discover natural substances that are effective in treating infertility.

To date, several studies have shown that natural products regulate endometrial autophagy and are effective as a treatment for infertility; however, there is no evidence of an association between their ability to control endometrial autophagy and improve infertility. Therefore, in this review, we discuss the correlation between the regulation of embryo implantation and endometrial autophagy after treatment with natural products. Additionally, this review suggests a new direction for research on the mechanism of infertility treatment with natural products.

\section{Autophagy}

Autophagy plays an important role in maintaining cellular homeostasis and energy levels. There are at least three forms of autophagy that depend on the cargo delivery system to the lysosome: macroautophagy, microautophagy, and chaperone-mediated autophagy (Figure 1). Macroautophagy, which is the primary autophagic pathway, refers to the formation of autophagosomes to collect cellular material, which subsequently fuses with lysosomes to break down the material. In contrast, in microautophagy, lysosomes directly engulf cytoplasmic cargo and degrade the material. Chaperone-mediated autophagy, which is unique to mammalian cells, involves a cargo recognition complex in the cytosol (heat shock protein 70 chaperone, Hsp70) and a cargo translation complex at the lysosome (lysosomal-associated membrane protein type 2A, Lamp2A). Hsp70 recognizes and attaches to a specific motif sequence in substrate proteins, and then the complex is delivered to Lamp2A in the lysosome membrane. The substrate protein is translocated to the lysosomal lumen for degradation by a lysosomal channel formed by Lamp2A [34]. 


\section{A. Macroautophagy}

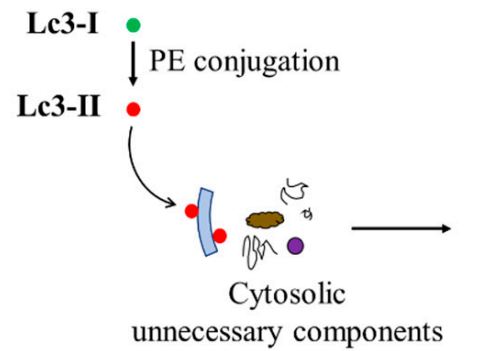

unnecessary components

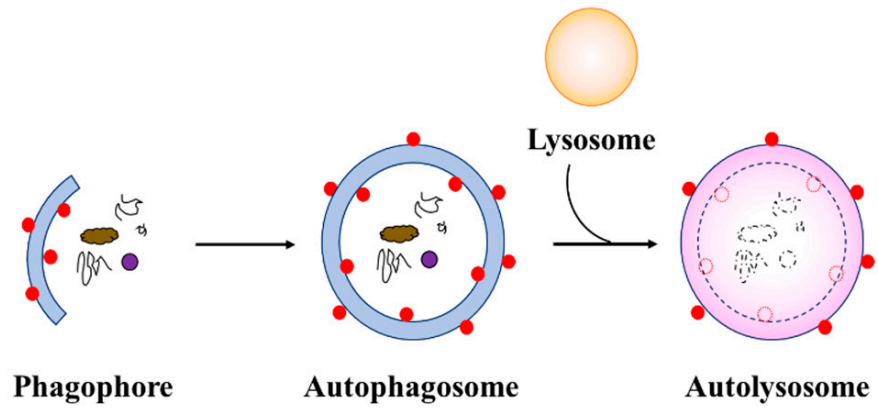

Phagophore

\section{B. Microautophagy}
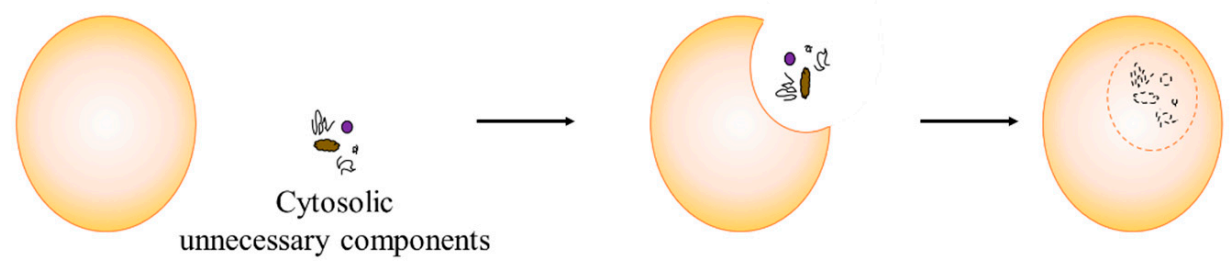

Lysosome

\section{Chaperon-mediated autophagy}

Substrate protein

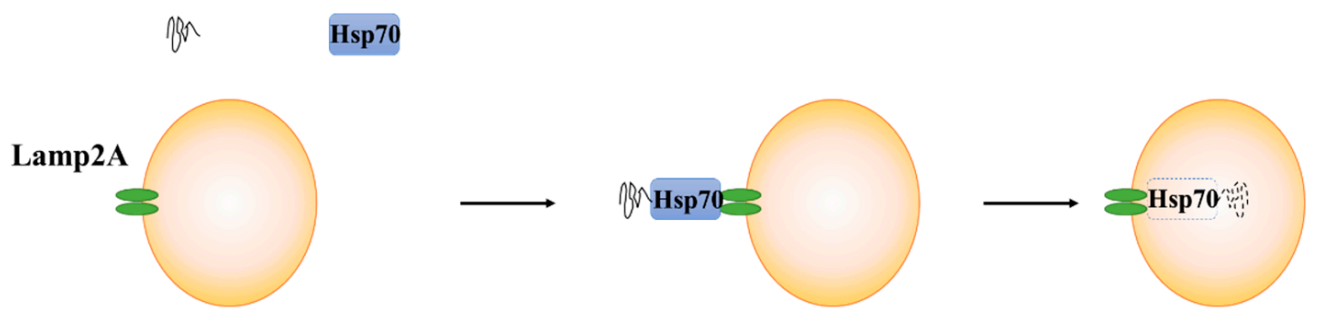

Lysosome

Figure 1. Three types of autophagy. There are three types of autophagy, depending on the cargo delivery system to the lysosome. (A) In macroautophagy, cytosolic components are sequestered within autophagosomes, which subsequently fuse with lysosomes. (B) By contrast, in microautophagy, lysosomes directly sequester the cytosolic components. (C) In chaperone-mediated autophagy, heat shock protein 70 chaperon (Hsp70) recognizes substrate proteins and delivers them to lysosomal-associated membrane protein type 2A (Lamp2A) in the lysosome membrane. The substrate proteins are translocated to the lysosomal lumen for degradation by lysosomal enzymes. Abbreviations: Atg, autophagy-related gene; Lc3, microtubule-associated protein 1 light chain 3; PE, phosphatidylethanolamine.

Macroautophagy (hereafter referred to as autophagy) removes and recycles intracellular components, such as damaged organelles and unnecessary proteins. Autophagic activity is low under normal conditions; however, it increases with nutrient starvation, infection, and accumulation of unused components [35]. Defects in autophagy lead to the disruption of intracellular homeostasis and have been reported to cause various diseases, including metabolic and neurodegenerative diseases as well as various types of cancer [36]. Therefore, it is important to understand the molecular basis of autophagy. However, the physiological roles of autophagy are still not fully understood owing to a lack of methods for assessing autophagic flux. Therefore, the importance of quantitative assay systems for autophagic flux has been identified as a critical barrier to understanding autophagy as a therapeutic target for diverse diseases. 


\section{Regulation of Autophagosome Formation}

Understanding the molecular basis of the formation and composition of cellular structures involved in autophagy is vital for improving our understanding of the process. As autophagy serves as a dynamic recycling machinery that maintains homeostasis for recycling cellular components and damaged organelles, the process is strictly regulated under physiological and pathological conditions [37]. The most important pathways for regulating autophagy are the mammalian target of rapamycin (mTOR) and AMP-activated protein kinase (AMPK) pathways [38,39]. AMPK, a key energy sensor and regulator of cellular metabolism, activates autophagy in response to ATP deficiency. Conversely, autophagy is inhibited by mTOR, a central cell-growth regulator that integrates growth factors and nutrition signals [39]. These two pathways counteract each other through phosphorylation of different serine residues of Unc-51 like kinase 1 (ULK1) or direct inhibition of mTOR1 by activated AMPK, thereby tightly regulating the initiation of autophagy $[38,40]$. Diverse stress conditions, such as nutrition starvation, growth factor deprivation, endoplasmic reticulum stress, viral infection, genotoxic stress, and oxidative stress, are known as physiological autophagy inducers [41-43]. Among the upstream regulators, liver kinase B1 (LKB1) is a master kinase of AMPK activation and serves as a metabolic checkpoint for cell growth in low nutrient conditions [44,45]. In addition, other stress conditions such as reactive oxygen species (ROS), which accumulate during glucose and amino acid deprivation, can also activate AMPK through activation of LKB1 or direct $S$-glutathionylation of cysteine residues on AMPK [42,46]. Other pathways, including p62/Keap1/Nrf2 and DNA damage response, also mediate the intercommunication between oxidative stress and autophagy [42].

Autophagosome formation can be divided into three stages: initiation, nucleation, and expansion (elongation). The process of autophagosome formation is shown in Figure 2. To initiate autophagy, the ULK complex (which contains the Ser/Thr kinases ULK1 and/or ULK2, autophagy-related protein 13 (Atg13), FAK family kinase-interacting protein of $200 \mathrm{kDa}$ (FIP200), and Atg101) and the class III phosphoinositide 3-kinase (PI3K-III) complex, also known as the Beclin1 complex (which is composed of vacuolar protein sorting 34 (Vps34), p150, Beclin1, and Atg14), are required. In mammalian cells, the ULK complex is bound to mTOR complex 1 (mTORC1) and is inactive under fed conditions. Upon amino acid starvation, the ULK complex dissociates from mTORC1 and is activated, resulting in increased kinase activities of ULK1 and ULK2. Next, the ULK complex binds to the membrane, which is the site of autophagosome initiation, and recruits the complexes for autophagosome nucleation [47]. The ULK complex phosphorylates the PI3K-III complex, which is equally important for autophagosome initiation and activates Vps34 lipid kinase.

Following autophagosome initiation, Vps34 generates phosphatidylinositol 3,4,5triphosphate (PI3P) on the membrane, which becomes a phagophore. These events drive the nucleation of the isolation membrane and recruit additional Atg proteins and autophagyspecific PI3P effectors, such as WD-repeat domain phosphoinositide-interacting 2 (Wipi2) and double FYVE-containing protein 1 (Dfcp1) [48]. During autophagosome nucleation, the interaction of PI3P with Wipi2 contributes to phagophore formation.

During expansion, the Atg12-Atg5-Atg16L1 complex (also known as the Atg16L1 complex) is recruited to the membrane, where it lipidates microtubule-associated protein 1 light chain 3 (MAP1-LC3, hereafter referred to as Lc3). Thus, Lc3 is associated with the autophagosomal membrane [49]. The association of cytosolic Lc3 proteins with the membrane occurs during the expansion of the isolation membrane. Before the closure of the isolation membrane, which becomes an autophagosome, the Atg proteins are dissociated from the membrane; however, lipidated Lc3 remains attached [50]. The Lc3 protein is thought to aid the expansion and closure of the isolation membrane [51,52] and its association with the autophagosomal membrane provides an important marker for identifying autophagosomes in cells. 


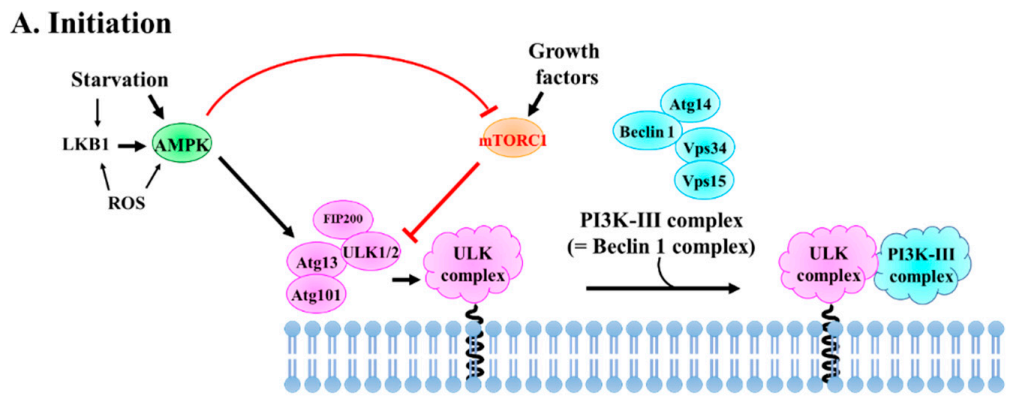

\section{B. Nucleation}

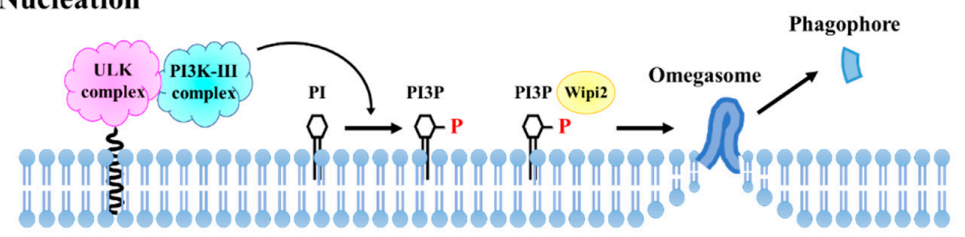

\section{Expansion}

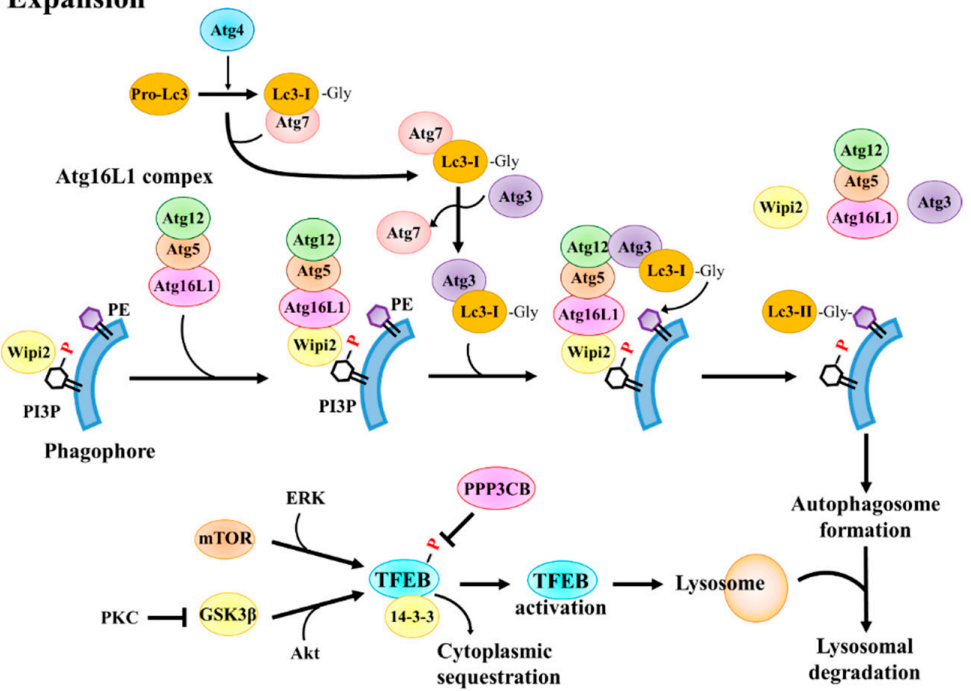

Figure 2. Autophagosome formation. Autophagosome formation can be divided into three stages. (A) During initiation, the UNC51-like kinase (ULK) complex is dissociated from mTORC1 and binds to the autophagosome initiation site. The ULK complex recruits and phosphorylates the class III phosphoinositide 3-kinase (PI3K-III) complex. (B) During nucleation, the PI3K-III complex generates phosphatidylinositol 3,4,5-triphosphate (PI3P) on the membrane and recruits autophagy-specific PI3P effectors, such as WD-repeat domain phosphoinositide-interacting 2 (Wipi2). The interaction of PI3P with Wipi2 contributes to the phagophore formation. (C) During expansion (elongation), the Atg12-Atg5-Atg16L1 complex (also known as the Atg16L1 complex) is recruited to the membrane and lipidates microtubule-associated proteins 1 light chain 3 (Lc3). The pro-form of Lc3 is cleaved at the carboxyl-terminal (C-terminal) by Atg4 and becomes cytosolic Lc3-I, thereby exposing the C-terminal glycine residue. Lc3-I is subsequently transferred to the autophagosome by Atg3 and conjugated with phosphatidylethanolamine (PE) at the C-terminal glycine residue by the Atg16L1 complex, resulting in the formation of Lc3-II. During the autophagy process, Lc3-II bound to the autophagosomal inner membrane is degraded by lysosomal enzymes. The expression of genes related to lysosomal biogenesis and autophagolysosome formation is controlled by a master transcriptional regulator, TFEB. Abbreviations: AMPK, AMP-activated protein kinase; Atg, autophagy-related gene; ERK, extracellular signal-regulated kinase; LKB1, liver kinase B1; GSK3 $\beta$, glycogen synthase kinase-3 $\beta$; mTOR, mechanistic target of rapamycin kinase; PKC, protein kinase $C$; PPP3CB, protein phosphatase 3 catalytic subunit beta; TFEB, transcription factor EB; Vps, vacuolar protein sorting-associated protein, Lc3, microtubule-associated proteins 1 light chain 3. 
There have been various suggestions regarding the origins of phagophore membranes and nucleation sites. These include de novo synthesis and pre-existing cellular membranes, such as the endoplasmic reticulum (ER), Golgi, mitochondria, endosomes, and the plasma membrane. However, recent data suggest that the ER is the most essential site for phagophore formation and elongation upon amino acid starvation, although the Golgi, mitochondria, plasma membrane, and endosomes also contribute to these events. The Golgi apparatus is essential for the trafficking of Atg9-containing vesicles and mitochondria supply lipid vesicles to the phagophore upon starvation. The plasma membrane is also a source of phagophore and autophagosome membranes under both basal and starvation conditions [47].

Lc3, a mammalian homolog of yeast Atg8, is widely used to measure autophagic activity. In humans, three paralogs of Lc3 have been reported: Lc3a, Lc3b, and Lc3c, which are encoded by the MAP1LC3A, MAP1LC3B, and MAP1LC3C genes, respectively. The cellular distribution, molecular function, and regulation of Lc3a and Lc3c have not yet been studied. Thus, Lc3b is commonly used in autophagy studies [53]. The Lc3 protein undergoes a series of post-translational modifications. The pro-form of Lc3b is cleaved at the carboxyl-terminal (C-terminal) by Atg4 and becomes cytosolic Lc3b-I, thereby exposing the C-terminal glycine residue. When autophagy is induced, Lc3b-I is subsequently transferred to the autophagosome by Atg3 and conjugated with phosphatidylethanolamine (PE) at the C-terminal glycine residue by the Atg16L1 complex, resulting in the formation of Lc3b-II [54]. The lipidated Lc3b-II is bound to both the outer and inner membranes of the autophagosome [55]. During the autophagy process, Lc3b-II bound to the autophagosomal inner membrane is degraded by lysosomal enzymes, whereas those located in the autophagosomal outer membrane are released into the cytosol and recycled [56]. Owing to this property, Lc3b is widely used as an autophagosome marker.

The fusion of autophagolysosomes with lysosomes is indispensable for the completion of the catabolic process of autophagy [57,58]. Transcription factor EB (TFEB), a member of the MiTF/TFE3 family, has been regarded as a master transcriptional regulator of lysosomal biogenesis $[59,60]$. The nuclear translocation and transcriptional activity of TFEB are controlled by the phosphorylation of specific serine residues. When serine residues including Ser122, Ser142, and Ser211 are phosphorylated, TFEB is inactive and localizes to the cytoplasm [61]. The Ser211 residue is crucial for binding to the 14-3-3 scaffold protein and subsequent cytoplasmic sequestration [62]. The phosphorylation of TFEB is mainly controlled by mTOR kinase and by phosphatase, protein phosphatase 3 catalytic subunit beta (PPP3CB) $[59,63]$. Other kinases, such as extracellular signal-regulated kinase (ERK), glycogen synthase kinase-3 $\beta$ (GSK3 $\beta$ ), and Akt, are also involved in the phosphorylation and cytoplasmic retention of TFEB $[60,64,65]$. However, the regulatory role of mTOR in nuclear translocation of TFEB is controversial. The phosphorylation of Ser462, Ser463, Ser466, Ser467, and Ser469, which are located at the C-terminus of TFEB, drive its nuclear translocation. These residues can be phosphorylated by mTOR or protein kinase C (PKC) $\beta[66,67]$. TFEB translocated into the nucleus regulates the expression of target genes bearing the coordinated lysosomal expression and regulation (CLEAR) motif, thereby participating in the formation and lysosomal fusion of autophagosomes as well as lysosomal biogenesis $[57,68]$. Thus, TFEB activity has been regarded as a potential target for modulating autophagy and lysosomal function for treating several pathological conditions, including cancer and neurodegenerative diseases $[59,69]$.

\section{Regulation of Embryo Implantation}

Pregnancy is a complex, but highly organized process that comprises multiple steps, including fertilization, implantation, decidualization, placentation, and the birth of offspring [70]. During the early stage of pregnancy, the endometrium undergoes major cellular changes, such as the receptiveness of the endometrial epithelium and decidualization of endometrial stromal cells (ESCs) [71]. The ability of the endometrium to allow embryo implantation is referred to as endometrial receptivity [18]. The features of endometrial 
receptivity include histological changes, such as angiogenesis, edema, and enhanced secretory activity of the endometrial glands $[19,72]$. Decidualization refers to significant changes occurring in uterine ESCs, including morphological and functional changes in ESCs, vascular changes to endometrial arteries, extracellular matrix remodeling, and the appearance of immune cells. Decidualization plays an important role in placental formation between the uterus and fetus by mediating the invasiveness of trophoblast cells [73].

These complex processes are regulated by diverse factors, including (1) the ovarian steroid hormones progesterone and estrogen, (2) the cytokines leukemia inhibitory factor (LIF) and interleukin 6 (IL6), and (3) growth factors such as transforming growth factor- $\beta$ (TGF- $\beta$ ) and heparin binding-epidermal growth factor (HB-EGF). These factors regulate the expression of several integrin molecules. Integrin molecules play a crucial role in the attachment of blastocysts to the uterine epithelium [74]. During the implantation period, ovarian steroids facilitate appropriate morphology, function, and development of the endometrium [75]. The endometrium in the mid-to-late-secretory phase, where the concentrations of ovarian steroid hormones are highest and implantation occurs, shows high expression levels of cytokines such as LIF and IL6 [76,77]. Cytokines play an important role in the adhesion between the endometrium and embryo during implantation and promote placental development. In particular, diminished secretion of LIF is associated with recurrent implantation failure (RIF) [78]. TGF- $\beta$ and HB-EGF are expressed in endometrial stromal and epithelial cells and have been reported to regulate endometrial cell proliferation and decidual transformation [74]. The major factors regulating endometrial receptivity and decidualization are summarized in Figure 3.

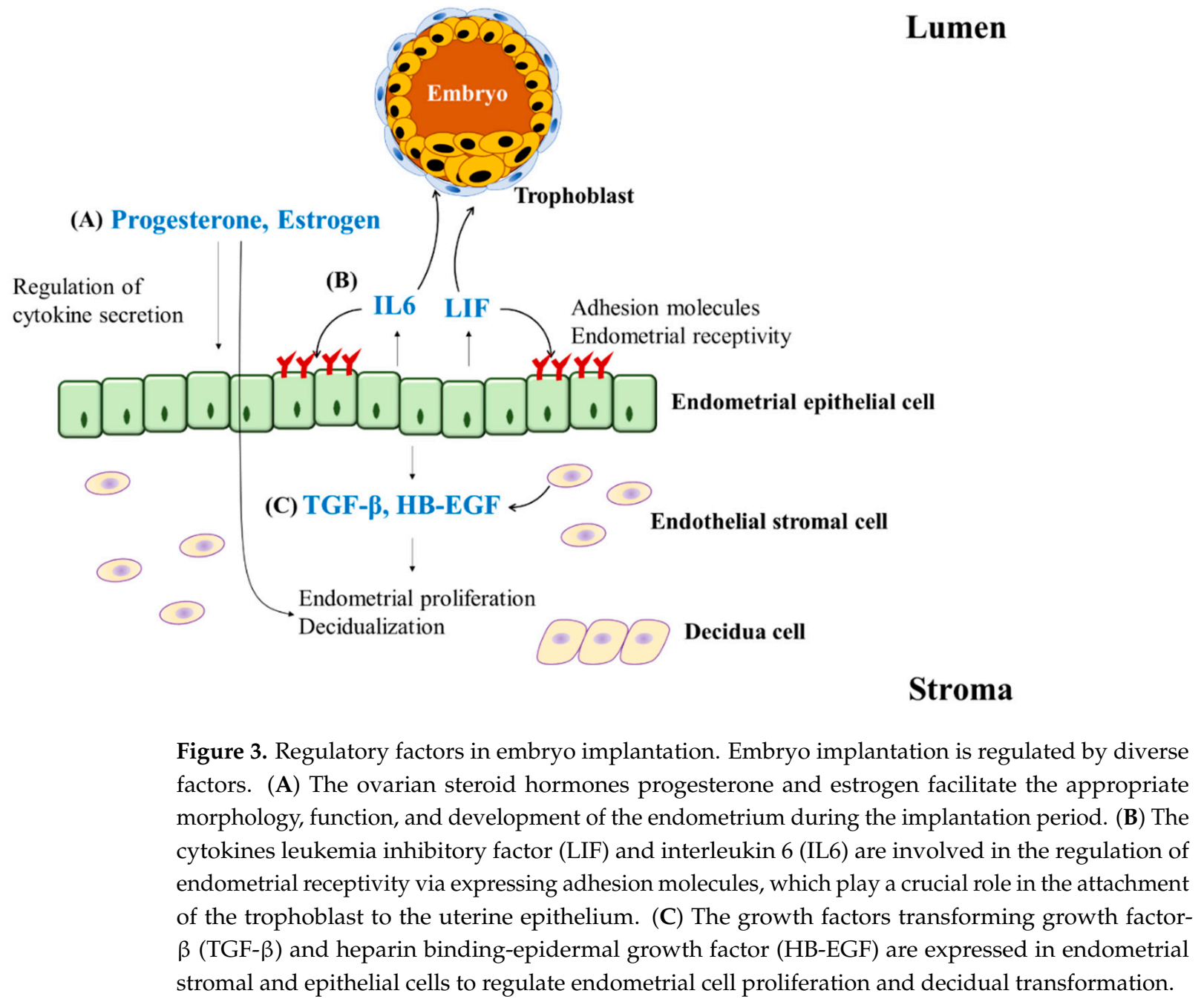


Although assisted reproductive technology (ART) has advanced, the implantation success rates of transferred embryos have not improved sufficiently [20,79]. A variety of studies, including those on growth factor treatment, immune therapy, platelet-rich plasma infusion, and intentional endometrial injury, have been conducted to improve the implantation rate [79-83]. However, there are very limited options for improving improper endometrial receptivity and decidualization [84]. Thus, more profound approaches are required to comprehend the molecular basis of embryo implantation and thereby identify novel therapeutics to improve the implantation rate.

\section{Role of Autophagy in Embryo Implantation}

Autophagy is a ubiquitous physiological process that plays diverse functions in different processes and diseases, both in stromal cells and epithelial cells in the endometrium [85-87]. Previously, Peters et al. [12] reviewed the role of autophagy in female infertility related to aged oocytes and the implication of oxidative stress in autophagy defects in age-related ovarian dysfunction. However, the role of autophagy in embryo implantation in the uterus remains largely unknown. During the menstrual cycle, the autophagic levels change dynamically. The autophagic level in normal ESCs is significantly higher in the secretory phase than in the proliferative phase [14]. However, in patients with endometriosis, ESCs in ectopic endometriosis foci show a constant autophagic level during the menstrual cycle [25]. Therapeutic approaches that inhibit or enhance autophagy have been reported as effective options in experimental endometriosis using rodent models [24,88-90]. Thus, whether the autophagic level is higher in normal or endometriotic tissues and whether the therapeutics induce or block autophagy are still being debated [91]. Although endometriosis is closely related to female infertility, in this review we focus on the role of autophagy in embryo implantation.

Among the processes of orchestrated events that are necessary for a successful pregnancy, two of the most critical steps are receptive endometrium and decidualization, which are required for maternal interactions with the developing embryo [71]. High-fat diet-induced obesity and palmitic acid treatment impair the decidualization of ESCs by reducing AMPK and ULK1 expression and decreasing autophagic flux [92]. Deficiency of folate, a major risk factor for birth defects, reduces the autophagy of endometrial cells, thereby inhibiting the apoptosis of decidual cells, restraining endometrial decidualization, and impairing early pregnancy [93].

Several systemic knockout studies have revealed that various ATG-related genes, including BECN1 (Beclin1), RB1CC1 (FIP200), and AMBRA1, are embryonically lethal with developmental defects [94-97]. However, the effects of these genes on embryo implantation have not been sufficiently investigated. Recent studies using genetic abrogation have shown that the autophagy of endometrial cells is closely involved in embryo implantation and decidualization [98,99]. Oestreich et al. [98], using a reproductive tract conditional knockout mouse model of RB1CC1, revealed that the autophagy protein FIP200 plays a key role in the development of ESCs to decidualized ESCs. They also demonstrated that Atg16L1 is necessary for proper decidualization and blastocyst implantation using mice with a hypomorphic allele of the Atg16L1 gene (causes a partial loss of function) [99]. In addition, cysteine-rich transmembrane BMP regulator 1 (CRIM1) functions as a regulator of endometrial receptivity at least in part by facilitating Atg7-dependent autophagy in the goat endometrium [100].

Pharmacological autophagy regulators have been examined to determine whether they affect the function of endometrial cells. Rapamycin, an autophagy inducer, reverses the impairment of endometrial decidualization in folate-deficient pregnant mice by disrupting AMPK/mTOR signaling [101]. In addition, Su et al. [16] suggested that autophagy is associated with endometrial decidualization during early pregnancy by revealing impaired uterine decidualization and reduced reproductive rate in female mice treated with the autophagy inhibitors 3-MA and chloroquine. Moreover, zearalenone, a mycotoxin isolated from several Fusarium species, blocks autophagic flux by inhibiting the fusion of autophago- 
somes and lysosomes, inducing the apoptosis of endometrial cells, and ultimately leading to the failure of embryo implantation in young female pigs [102]. Collectively, these reports indicate that endometrial autophagy is essential for embryo implantation, thereby playing a crucial role in endometrial receptivity, decidualization, and subsequent fertility sustenance during early pregnancy (Figure 4).

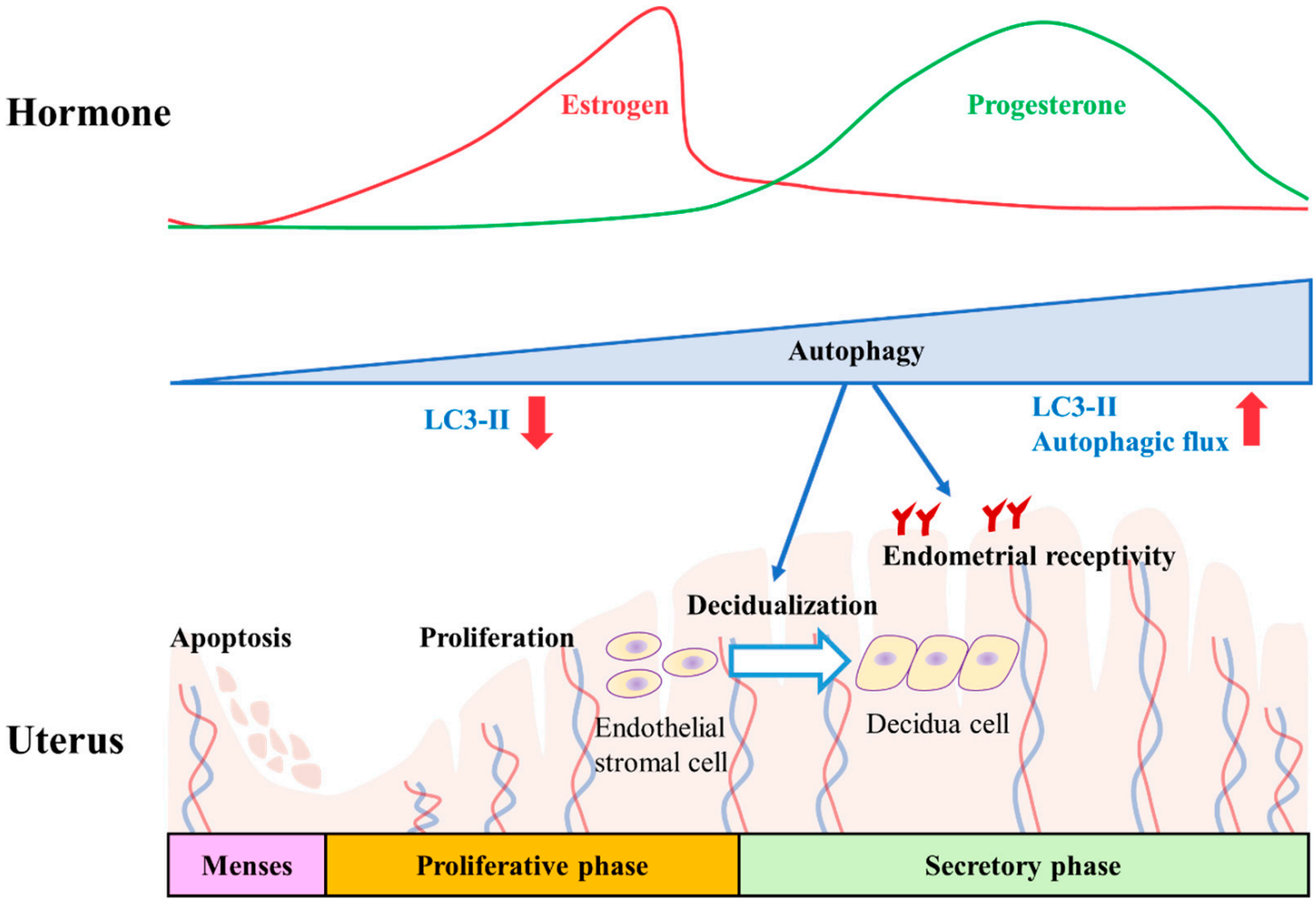

Figure 4. Role of autophagy in embryo implantation. Cyclic changes in ovarian steroid hormones, including estrogen and progesterone, regulate the growth, differentiation, and apoptosis of endometrial cells in the different phases of the uterine endometrium. The levels of Lc3-II and flux of autophagy are increased in the secretory phase, correlating with the level of progesterone. Defects of autophagy directly affect the receptivity of endometrial epithelium and decidualization of endometrial stromal cells. Abbreviation: LC3, microtubule-associated proteins 1 light chain 3.

\section{Potential Involvement of Autophagic Regulation on the Effect of Natural Products as Embryo Implantation Enhancer}

As summarized above, autophagy is increased in the secretory phase of the menstrual cycle and plays a key role in embryo implantation by inducing changes in the uterine endometrium, including endometrial receptivity and decidualization. However, the roles of autophagy-enhancing natural products have not been thoroughly investigated to improve embryo implantation. To date, various natural compounds have been screened and reported as regulators of autophagy [29,30]. Among the various natural compounds that have been identified as autophagy activators, we selected and organized only natural products that have been proven to be safe, are approved by the United States Food and Drug Administration (FDA), and have effects on female fertility (Table 1). Although the direct mechanisms underlying the correlation between autophagy activation and the efficiency of female fertility are still unclear, 20 natural products have been suggested as inhibitors or enhancers of female fertility and have been shown to activate autophagy.

Among these autophagy inducers derived from natural products, 10 compounds, berberine, brefeldin A, curcumin, chrysin, fisetin, $\alpha$-mangostin, paeoniflorin, rapamycin, $\gamma$-tocotrienol, and ursolic acid, have been reported to enhance the female fertility rate by reducing polycystic ovary syndrome (PCOS) and ovarian cell death, protecting the ovary 
from damage, and improving embryo quality and ovarian life span [103-117]. Several of the 10 natural compounds that improve fertility, including berberine, paeoniflorin, ursolic acid, and deferoxamine, have been reported to ameliorate endometriosis [103,118-121]. Endometriosis is a major cause of female infertility and is associated with reduced oocyte quality and implantation failure $[122,123]$.

Of the 20 natural products that we examined, only nine were found to be directly related to embryo implantation. Four compounds, apigenin, curcumin, genistein, and quercetin, were identified as antagonists for embryo implantation [124-130]. Four compounds, berberine, emodin, paeoniflorin, and $\gamma$-tocotrienol, increased implantation rates by increasing endometrial receptivity or decidualization [103,116,120,131,132]. In contrast, resveratrol has been shown to have dual effects as an agonist and antagonist $[133,134]$. Kuroda et al. [135] compared these reports and concluded that the timing of drug treatment is important in modulating the decidual response. Resveratrol treatment during the initial decidual phase (i.e., coinciding with the implantation window in vivo) inhibits decidual transformation. However, after the initial phase, resveratrol may promote decidualization by inhibiting decidual senescence. Collectively, the compounds berberine, emodin, paeoniflorin, and $\gamma$-tocotrienol might be potential candidates that can increase the rate of embryo implantation, although their effectiveness still requires further investigation.

Several studies have been conducted on the pharmacological or genetic abrogation of autophagy [98-101], and the role of autophagy in embryo implantation has been largely elucidated. However, the effects of autophagic activators on embryo implantation are not uniform, although the pathways of autophagy activation by these compounds are similar. There are several possible reasons for this heterogeneity. First, the off-target effects of natural products may be different and result in different outcomes. Second, other factors may exist in the "natural products-autophagy activation-embryo implantation" axis. Finally, incomplete autophagic flux may be a source of inconsistency. For example, zearalenone increases Lc3 activation and autophagosome formation, but blocks autophagic flux, thereby leading to implantation failure in gilt [102]. Therefore, further studies should be conducted to develop novel drug candidates to reduce implantation failure by inducing autophagy. 
Table 1. Effects of natural product autophagy regulators on female fertility.

\begin{tabular}{|c|c|c|c|c|c|c|}
\hline Classification & Name & Chemical Structure & Biological Action & $\begin{array}{l}\text { Autophagy-Related Mode } \\
\text { of Action }\end{array}$ & $\begin{array}{l}\text { Effect on Female } \\
\text { Reproduction }\end{array}$ & References \\
\hline $\begin{array}{l}\text { Acetohydroxamic } \\
\text { acids }\end{array}$ & Deferoxamine & & Antibacterial and heavy metal antagonist & $\begin{array}{l}\text { mTOR inhibition; } \\
\text { elevation of LC3B } \\
\text { expression }\end{array}$ & $\begin{array}{l}\text { Protects endometrial } \\
\text { stem cells from } \\
\text { oxidative damage }\end{array}$ & {$[118,119,136]$} \\
\hline Alkaloid & Berberine & & $\begin{array}{l}\text { Antioxidant, anticancer, atheroprotective, and } \\
\text { immune modulator }\end{array}$ & $\begin{array}{l}\text { Activation of Beclin1; } \\
\text { mTOR inhibition }\end{array}$ & $\begin{array}{l}\text { Improves ovulation and } \\
\text { endometrial receptivity }\end{array}$ & {$[103,137-139]$} \\
\hline Anthraquinone & Emodin & & Antioxidant, antidiabetic, and anticancer & $\begin{array}{l}\text { Elevation of LC3-II } \\
\text { expression }\end{array}$ & $\begin{array}{l}\text { Increases the MET of the } \\
\text { endometrial stromal cell } \\
\text { (decidualization) }\end{array}$ & {$[131,132,140,141]$} \\
\hline \multirow{4}{*}{ Flavonoid } & Apigenin & & Antioxidant and anticancer & mTOR inhibition & $\begin{array}{l}\text { Protects the ovary from } \\
\text { ischemic/reperfusion } \\
\text { and chemother- } \\
\text { apy;antagonizes to } \\
\text { progesterone; inhibits } \\
\text { embryo implantation }\end{array}$ & {$[124,142-144]$} \\
\hline & Chrysin & & Antioxidant, neuroprotective, and anticancer & $\begin{array}{l}\text { Reduction in LC3-II, } \\
\text { Beclin1, and ATG7 levels }\end{array}$ & $\begin{array}{l}\text { Protects the ovary from } \\
\text { ischemic/reperfusion }\end{array}$ & {$[110,145,146]$} \\
\hline & Fisetin & & Antioxidant, neuroprotective, and anticancer & $\begin{array}{l}\text { mTOR inhibition; AMPK } \\
\text { activation }\end{array}$ & Reduces PCOS & {$[111,147,148]$} \\
\hline & Genistein & & Antioxidant, anti-inflammatory, and anticancer & $\begin{array}{l}\text { Inhibition of PI3K-AKT; } \\
\text { enhancement of TFEB } \\
\text { activity }\end{array}$ & $\begin{array}{l}\text { Induces implantation } \\
\text { failure in neonate mice, } \\
\text { but not in puberty }\end{array}$ & {$[126-128,149]$} \\
\hline
\end{tabular}


Table 1. Cont.

\begin{tabular}{|c|c|c|c|c|c|c|}
\hline Classification & Name & Chemical Structure & Biological Action & $\begin{array}{l}\text { Autophagy-Related Mode } \\
\text { of Action }\end{array}$ & $\begin{array}{l}\text { Effect on Female } \\
\text { Reproduction }\end{array}$ & References \\
\hline \multirow{3}{*}{ Flavonoid } & Kaempferol & & Antioxidant, neuroprotective, and anticancer & AMPK activation & $\begin{array}{l}\text { Increases follicle } \\
\text { development;activates } \\
\text { progesterone signal; } \\
\text { relaxes uterine } \\
\text { smooth muscle }\end{array}$ & [150-155] \\
\hline & Quercetin & & Antioxidant, antiviral, and anticancer & $\begin{array}{l}\text { Induction of ATG5 and } \\
\text { AMPK activation }\end{array}$ & $\begin{array}{l}\text { Improves follicular } \\
\text { development and oocyte } \\
\text { quality;inhibits } \\
\text { embryo implantation }\end{array}$ & {$[129,130,156-158]$} \\
\hline & Wogonin & & $\begin{array}{l}\text { Antioxidant, neuroprotective, } \\
\text { anti-inflammation, and anticancer }\end{array}$ & $\begin{array}{l}\text { Induction of ER stress; } \\
\text { elevation of LC3-II and } \\
\text { Beclin1 levels }\end{array}$ & $\begin{array}{l}\text { Relaxes uterine } \\
\text { smooth muscle }\end{array}$ & [159-161] \\
\hline \multirow{2}{*}{ Lactone } & Rapamycin & & $\begin{array}{l}\text { Antibacterial, anticancer, and } \\
\text { immunosuppressant }\end{array}$ & mTOR inhibition & $\begin{array}{l}\text { Increases ovarian } \\
\text { lifespan }\end{array}$ & {$[115,162,163]$} \\
\hline & Brefeldin A & & Antiviral and protein transport inhibitor & $\begin{array}{l}\text { Enhancement of Bip/AKT } \\
\text { activation; reduction in } \\
\text { AKT phosphorylation }\end{array}$ & $\begin{array}{l}\text { Increases the survival of } \\
\text { female germ cells }\end{array}$ & {$[104-107,164]$} \\
\hline
\end{tabular}


Table 1. Cont.

\begin{tabular}{|c|c|c|c|c|c|c|}
\hline Classification & Name & Chemical Structure & Biological Action & $\begin{array}{l}\text { Autophagy-Related Mode } \\
\text { of Action }\end{array}$ & $\begin{array}{l}\text { Effect on Female } \\
\text { Reproduction }\end{array}$ & References \\
\hline Lignan & Magnolol & & Antioxidant, antidiabetic, and anticancer & mTOR inhibition & $\begin{array}{l}\text { Inhibits uterine smooth } \\
\text { muscle contraction }\end{array}$ & [165-168] \\
\hline \multirow{2}{*}{ Polyphenol } & Curcumin & & $\begin{array}{l}\text { Antioxidant, antidiabetic, antiallergic, and } \\
\text { anticancer }\end{array}$ & $\begin{array}{l}\text { Inhibition of mTOR; } \\
\text { enhancement of TFEB } \\
\text { activity and LC3 levels }\end{array}$ & $\begin{array}{l}\text { Reduces PCOS and } \\
\text { POF;inhibits } \\
\text { decidualization }\end{array}$ & {$[108,109,125,169-171]$} \\
\hline & $\begin{array}{l}\text { EGCG, catechin, } \\
\text { and epicatechin }\end{array}$ & & $\begin{array}{l}\text { Antioxidant, neuroprotective, } \\
\text { anti-inflammation and anticancer }\end{array}$ & AMPK activation & $\begin{array}{l}\text { Enhance ovulation; } \\
\text { reduce cyst formation in } \\
\text { PCOS }\end{array}$ & [172-176] \\
\hline Stilbenoid & Resveratrol & & $\begin{array}{l}\text { Antioxidant, neuroprotective, antidiabetic, } \\
\text { and anticancer }\end{array}$ & AMPK activation & $\begin{array}{l}\text { Improves oocyte } \\
\text { maturation in } \\
\text { aged;increases or } \\
\text { decreases } \\
\text { decidualization }\end{array}$ & [133-135,177-180] \\
\hline \multirow{3}{*}{ Terpenoid } & Paeoniflorin & & $\begin{array}{l}\text { Antioxidant, anti-inflammatory, } \\
\text { neuroprotective, and anticancer }\end{array}$ & LKB1/AMPK activation & $\begin{array}{l}\text { Reduces PCOS;enhances } \\
\text { endometrial receptivity }\end{array}$ & {$[113,114,120,181-183]$} \\
\hline & & & & & & \\
\hline & Ursolic acid & & $\begin{array}{l}\text { Antioxidant, atheroprotective, antidiabetic, } \\
\text { and anticancer }\end{array}$ & $\begin{array}{l}\text { mTOR inhibition; } \\
\text { elevation of LC3-II, ATG5, } \\
\text { and Beclin1 levels }\end{array}$ & $\begin{array}{c}\text { Attenuates POF (hypo- } \\
\text { thetical);suppresses } \\
\text { endometrial stromal cell } \\
\text { survival }\end{array}$ & {$[117,121,184-186]$} \\
\hline
\end{tabular}


Table 1. Cont.

\begin{tabular}{|c|c|c|c|c|c|c|}
\hline Classification & Name & Chemical Structure & Biological Action & $\begin{array}{c}\text { Autophagy-Related Mode } \\
\text { of Action }\end{array}$ & $\begin{array}{l}\text { Effect on Female } \\
\text { Reproduction }\end{array}$ & References \\
\hline Tocotrienol & $\gamma$-Tocotrienol & & Antioxidant, anti-inflammatory, and anticancer & $\begin{array}{l}\text { AMPK activation; } \\
\text { elevation of LC3-II, ATG5, } \\
\text { and Beclin1 levels }\end{array}$ & $\begin{array}{c}\text { Promotes } \\
\text { preimplantation } \\
\text { development; improves } \\
\text { the quality of embryos }\end{array}$ & {$[116,187,188]$} \\
\hline Xanthonoid & $\alpha$-Mangostin & & Antioxidant, neuroprotective, and anticancer & $\begin{array}{l}\text { AMPK activation; } \\
\text { induction of LC3-II }\end{array}$ & $\begin{array}{l}\text { Protects from ovarian } \\
\text { cell death }\end{array}$ & {$[112,189,190]$} \\
\hline
\end{tabular}

Abbreviations: MET, mesenchymal-epithelial transition; PCOS, polycystic ovary syndrome; POF, premature ovarian failure; ATG, autophagy-related gene; mTOR, mammalian target of rapamycin kinase; AMPK, AMP-activated protein kinase; LC3, microtubule-associated protein 1 light chain 3 . The chemical structures of compounds were created with ChemDraw (PerkinElmer, Waltham, MA, USA) 


\section{Possible Role of Autophagy on the Effect of Medicinal Herbal Drugs as Embryo Implantation Enhancer}

As shown in Table 2, traditional herbal medicines have been used to treat female infertility [191]. Several reports have suggested that traditional herbal formulas and medicinal herbs successfully improve endometrial receptivity and might be an alternative option for improving the outcome of embryo implantation [192-194]. Many herbal formulas have been studied for enhancing the embryo implantation rate in animal studies and clinical study [195-213]. Among these formulas, Erbu Zhuyu decoction and Tokishakuyakusan (TJ-23, Danggui Shaoyao san in Chinese) have been reported to induce autophagy via the expression of Beclin1 and LC3 [208,214,215]. However, as the induction of autophagy in Tokishakuyakusan was not examined in the uterine endometrium, it is not clear whether autophagy activation is directly related to the enhancement of endometrial receptivity.

Medicinal plants have also been studied to improve the rate of embryo implantation. Decusirol isolated from Angelica gigas enhanced endometrial receptivity [216] and Theobroma cacao and American ginseng increased preimplantation potential without any reproductive toxicity $[217,218]$. Theobroma cacao was reported as an autophagic inducer through the activation of sirtuin-1/AMPK signaling in liver and kidney cells $[219,220]$. However, decusirol blocked autophagic flux by suppressing the expression of the lysosomal enzyme cathepsin $C$ in gastric cancer cells [221]. Our previous studies showed that several medicinal plants, including Cnidium officinale, Cyperus rotundus, Paeonia lactiflora, Perilla frutescens var. acuta, and Rehmannia glutinosa var. purpurae, have a positive effect on improving endometrial receptivity by increasing LIF expression and integrin adhesion molecules [222-225]. Among these, perillaldehyde from Perilla frutescens var. acuta, and catalpol from Rehmannia glutinosa var. purpurea induces autophagy by activating AMPK signaling [226-228]. Cyperus rotundus is also known to induce autophagy by increasing LC3 and Beclin1 expression [229]. The major active compound responsible for autophagy activation has not yet been elucidated. In particular, the extract from the roots of P. lactiflora Pall. improved endometrial receptivity [225]. Paeoniflorin is the main active ingredient of P. lactiflora for increasing endometrial receptivity via LIF expression [120]. In addition, paeoniflorin has been reported to induce autophagy and AMPK activation in several types of cells $[114,230,231]$.

These studies have shown that diverse medicinal plants and herbal formulas enhance endometrial receptivity and induce autophagy. The proposed autophagic mechanisms of medicinal formulas and herbal drugs, which are reported as enhancers of embryo implantation, are summarized in Figure 5. However, there is direct evidence that autophagy is directly related to the implantation-promoting effects of these herbal formulas and medicinal herbs. Only Erbu Zhuyu decoction was examined for the expression of autophagic proteins, Beclin1 and LC3B, in the uterine endometrium. In addition, the major active compounds of medicinal compounds that increase autophagy are largely unknown. Diverse natural products used for female infertility have potent antioxidant activity [232], therefore the reduction in oxidative stress could be a possible mechanism underlying their autophagic regulation and improved embryo implantation. The expression of oxidative stress-related genes is involved in idiopathic recurrent miscarriage [233]. In patients suffering from RIF, downregulation of sirtuin-1, a regulator of ROS homeostasis, impeded endometrial decidualization [234]. Resveratrol, an autophagy inducer, restored zearalenone-induced impaired decidualization through induction of the antioxidative gene glutathione peroxide 3 [235]. However, although oxidative stress can increase autophagy initiation, autophagy also contributes to the clearance of irreversibly oxidized molecules [42]. Thus, the relationship between oxidative stress and autophagy remains controversial. To improve our understanding of the mode of action of these herbal medicines and to develop novel therapeutic options to enhance endometrial receptivity, more intensive studies should be performed from the viewpoint of autophagy. 


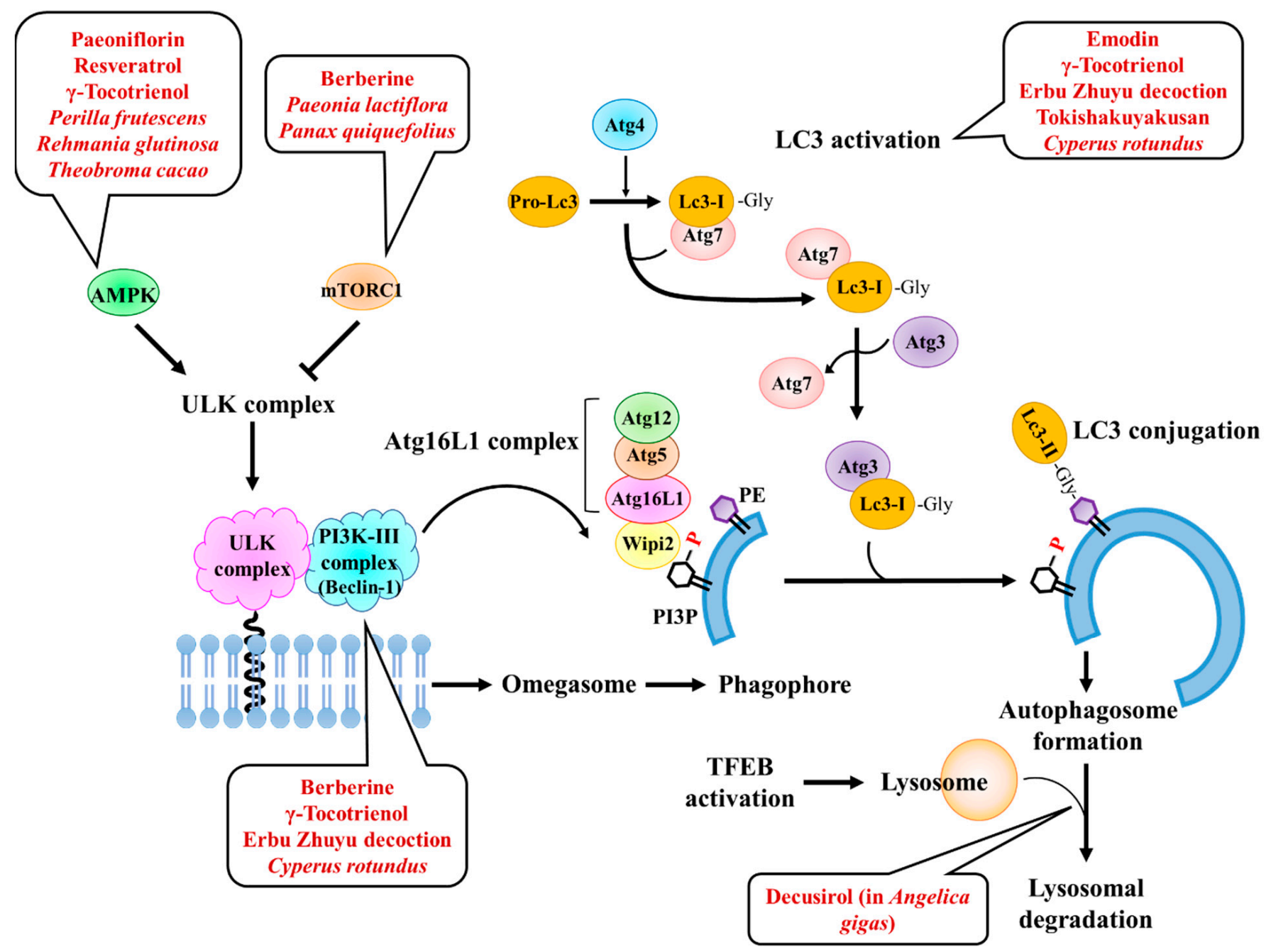

Figure 5. The proposed mechanisms of natural products that enhance embryo implantation. Paeoniflorin, resveratrol, $\gamma$-Tocotrienol, Perilla frutescens, Rehmannia glutinosa, and Theobroma cacao activate AMPK and thereby induce autophagy. Berberine, Paeonia lactiflora, and Panax quinquefolius inactivates mTORC1. Berberine, $\gamma$-Tocotrienol, Erbu Zhuyu decoction, and Cyperus rotundus reduced Beclin1. Emodin, $\gamma$-Tocotrienol, Erbu Zhuyu decoction, Tokishakuyakusan, and Cyperus rotundus increase LC3 expression and/or its activation. Decusirol isolated from Angelica gigas interferes with autophagic flux. Abbreviations: AMPK, AMP-activated protein kinase; Atg, autophagy-related gene; mTOR, mammalian target of rapamycin kinase; Lc3, microtubule-associated proteins 1 light chain 3. 
Table 2. Effect of traditional herbal medicines improving endometrial receptivity on autophagy.

\begin{tabular}{|c|c|c|c|}
\hline Name & Active Components & Role in Autophagy & References \\
\hline BaelanChagsangBang & - & - & [236] \\
\hline Bangdeyun and its component DS147 & - & - & {$[196,197]$} \\
\hline Buganshen recipe & - & - & [198] \\
\hline BuShenAnTai recipe & - & - & [201] \\
\hline $\begin{array}{c}\text { Bushen Tiaoxue Granules and Kunling } \\
\text { Wan }\end{array}$ & - & - & [202] \\
\hline Dingkun Pill & - & - & {$[206,207,212]$} \\
\hline Erbu Zhuyu decoction & - & Increases the Beclin1 and LC3B & {$[204,208]$} \\
\hline Gushen'antai pills & - & - & [195] \\
\hline Liuwei Dihuang Granule & - & - & [199] \\
\hline Shoutaiwai recipe & - & - & [200] \\
\hline Tokishakuyakusan(Danggui Shaoyao san) & - & $\begin{array}{l}\text { Induces autophagy and mitophagy } \\
\text { via increasing PINK1 and LC } 3 \text { but } \\
\text { reducing p62 }\end{array}$ & {$[203,214,215]$} \\
\hline Wenshen Yangxue decoction & - & - & {$[205,211]$} \\
\hline Xianziyizhen Recipe & - & - & [237] \\
\hline Yeosin-san & $\begin{array}{l}\text { Paeonia lactiflora and } \\
\text { Cyperus rotundus }\end{array}$ & - & {$[213,238]$} \\
\hline Yiqixue buganshen recipe & - & - & [198] \\
\hline Zhuyun recipe & - & - & [210] \\
\hline Angelica gigas & Decusirol & $\begin{array}{l}\text { Block autophagic flux by suppressing } \\
\text { cathepsin } C \text { expression }\end{array}$ & {$[216,221]$} \\
\hline Cnidium officinale & - & - & [239] \\
\hline Cyperus rotundus & - & Increases LC3B II/LC3B and Beclin1 & {$[223,229]$} \\
\hline Paeonia lactiflora & Paeoniflorin & $\begin{array}{l}\text { Induces autophagy via inhibition of } \\
\text { AKT } / \mathrm{mTOR}\end{array}$ & {$[114,225,230]$} \\
\hline Panax quiquefolius (American Ginseng) & $\begin{array}{l}\text { Ginsenoside } \mathrm{Rb} 1 \text { and } \\
\text { Rg1 }\end{array}$ & $\begin{array}{c}\text { Induces autophagy via inhibiting } \\
\text { AKT/mTOR }\end{array}$ & {$[218,240,241]$} \\
\hline Perilla frutescens var. acuta & Perilaldehyde & $\begin{array}{c}\text { Induces autophagy via activating } \\
\text { AMPK }\end{array}$ & {$[222,228]$} \\
\hline Rehmannia glutinosa var. purpurea & Catalpol & $\begin{array}{c}\text { Induces autophagy via activating } \\
\text { AMPK }\end{array}$ & {$[224,226,227]$} \\
\hline Theobroma cacao & - & $\begin{array}{c}\text { Induces autophagy via activating } \\
\text { sirtuin-1/AMPK signaling }\end{array}$ & {$[217,219,220]$} \\
\hline
\end{tabular}

Abbreviations: mTOR, mammalian target of rapamycin kinase; AMPK, AMP-activated protein kinase; LC3, microtubule-associated protein 1 light chain 3.

Although traditional herbal medicines are generally regarded as safe for use in the clinic, the scientific basis for safety issues is still insufficient. Several herbal medicines and essential oils have been reported to cause harmful adverse outcomes, including fetal resorption, teratogenicity, and embryo-fetotoxicity after maternal exposure [242,243]. Among the medicinal herbs listed in Table 2, Chinese Angelica, a root of the Angelica genus, white Paeony root, a root of $P$. lactiflora, and $\beta$-elemene, a compound contained in C. rotundus, have been reported to increase the rate of adverse effects. Several herbal drugs, such as Lippa citriodora leaves and large head Atractylodes roots, have shown teratogenic adverse effects [244,245]. In contrast, another study reported that white Paeony root does not induce any harmful adverse effects up to the highest dose tested of $32 \mathrm{~g} / \mathrm{kg} /$ day [246]. In addition, 
safety assessment of products containing Angelica extract demonstrated no adverse effects when used during pregnancy $[247,248]$. Moreover, the whole extract of Korean ginseng and American ginseng does not increase harmful adverse effects in pregnant mice [218,249], although ginsenoside $\mathrm{Rb} 1$ retarded early pre- and post-implantation development of mouse embryos by inducing ROS-mediated apoptosis [250]. To precisely evaluate safety issues, further good laboratory practice (GLP)-level reproductive toxicity studies should be conducted. Currently, caution should be exercised in the clinical use of medicinal herbal drugs during pregnancy.

\section{Conclusions and Perspective}

Successful pregnancy requires a sequence of orchestrated events, including embryo implantation and decidualization [18,71]. These steps are critical for maintaining early pregnancy because they mediate the interaction between the maternal uterus and the developing embryo. If the embryo implantation and decidualization processes are unsuccessful or improperly regulated, it may result in the loss of early pregnancy, RIF, or pre-eclampsia [18,70]. Recent studies have demonstrated that autophagy is elevated in the secretory phase of the menstrual cycle and is positively related to the formation of the receptive endometrium $[15,16]$. Additionally, the decidualization process is mediated by a highly regulated autophagy process [101]. Thus, autophagy may be a therapeutic target for improving embryo implantation.

Diverse natural products have been reported to be autophagy inducers, and many researchers are attempting to find novel therapeutic agents for the treatment of autophagydefective diseases, including cancer, neurodegenerative diseases, and aging $[29,30,251]$. Thus, natural products can be applied to improve the embryo implantation rate in an autophagy-dependent manner. However, to date, only a few studies have focused on the topic of autophagy as a major mechanism underlying the improvement of embryo implantation, and thereby the treatment of female infertility by natural products. In addition, the present autophagy inducers showed limitations due to their low specificity, irregular distribution, and rapid clearance [59]. To encourage the development of novel drug candidates for treating autophagy-related female infertility, the following two strategies might be helpful. Formerly, natural product-based autophagy inducers could be structurally modified to enhance efficacy, specificity, bioavailability, and safety [252,253]. Nano-delivery of natural products might be an option to improve aqueous solubility, bioavailability, and distribution to specific tissues $[59,254]$. Several studies have shown that natural product-loaded nanoparticles, including the autophagy inducers resveratrol, quercetin, and curcumin are promising for the treatment of various diseases such as cancer, inflammation, and arthritis [255]. Toxicity concerns should be addressed before their clinical use in female infertility patients.

There are several reasons for the limited scope of this review. First, the mechanism of embryo implantation is still largely unknown, particularly its relationship with autophagy. Second, there are not many pro-autophagic drug candidates that are safe for use in early pregnancy. Third, in vivo methods for monitoring autophagic flux have not been fully developed. Thus, these limitations should be addressed in future studies to elucidate the precise role of autophagy in embryo implantation and to identify potential candidates for treating female infertility from the perspective of endometrial receptivity and decidualization in early pregnancy.

Author Contributions: Conceptualization, J.J. and K.-T.H.; methodology and formal analysis, H.P., Y.D. and J.-K.P.; data curation, M.C. and S.-J.B.; writing—original draft preparation, H.P. and M.C.; writing -review and editing, S.-J.B., J.J. and K.-T.H.; supervision, J.J. and K.-T.H.; funding acquisition, J.J. All authors have read and agreed to the published version of the manuscript.

Funding: This work was supported by a National Research Foundation of Korea (NRF) grant funded by the Korean government (MIST) (No. NRF-2020R1F1A1067185 and 2021R1A4A1025662).

Institutional Review Board Statement: Not applicable. 


\section{Informed Consent Statement: Not applicable.}

Data Availability Statement: The data will be made available upon reasonable request.

Conflicts of Interest: There are no conflicts of interest to declare.

\section{References}

1. Mizushima, N. A brief history of autophagy from cell biology to physiology and disease. Nat. Cell Biol. 2018, 20, 521-527. [CrossRef]

2. Jung, M.; Choi, H.; Mun, J.Y. The autophagy research in electron microscopy. Appl. Microsc. 2019, 49, 11. [CrossRef]

3. Takeshige, K.; Baba, M.; Tsuboi, S.; Noda, T.; Ohsumi, Y. Autophagy in yeast demonstrated with proteinase-deficient mutants and conditions for its induction. J. Cell Biol. 1992, 119, 301-311. [CrossRef]

4. Ke, P.Y. Horning cell self-digestion: Autophagy wins the 2016 nobel prize in physiology or medicine. Biomed. J. 2017, 40, 5-8. [CrossRef]

5. Levine, B.; Klionsky, D.J. Autophagy wins the 2016 nobel prize in physiology or medicine: Breakthroughs in baker's yeast fuel advances in biomedical research. Proc. Natl. Acad. Sci. USA 2017, 114, 201-205. [CrossRef]

6. Eskelinen, E.L. Autophagy: Supporting cellular and organismal homeostasis by self-eating. Int. J. Biochem. Cell Biol. 2019, 111, 1-10. [CrossRef]

7. Poon, A.; Eidelman, D.; Laprise, C.; Hamid, Q. Atg5, autophagy and lung function in asthma. Autophagy 2012, 8, 694-695. [CrossRef]

8. Pierdominici, M.; Vomero, M.; Barbati, C.; Colasanti, T.; Maselli, A.; Vacirca, D.; Giovannetti, A.; Malorni, W.; Ortona, E. Role of autophagy in immunity and autoimmunity, with a special focus on systemic lupus erythematosus. FASEB J. 2012, 26, 1400-1412 [CrossRef]

9. Koukourakis, M.I.; Giatromanolaki, A.; Sivridis, E.; Pitiakoudis, M.; Gatter, K.C.; Harris, A.L. Beclin 1 over- and underexpression in colorectal cancer: Distinct patterns relate to prognosis and tumour hypoxia. Br. J. Cancer 2010, 103, 1209-1214. [CrossRef]

10. Trinh, J.; Farrer, M. Advances in the genetics of parkinson disease. Nat. Rev. Neurol. 2013, 9, 445-454. [CrossRef]

11. Tian, Y.; Li, Z.; Hu, W.; Ren, H.; Tian, E.; Zhao, Y.; Lu, Q.; Huang, X.; Yang, P.; Li, X.; et al. C. Elegans screen identifies autophagy genes specific to multicellular organisms. Cell 2010, 141, 1042-1055. [CrossRef]

12. Peters, A.E.; Mihalas, B.P.; Bromfield, E.G.; Roman, S.D.; Nixon, B.; Sutherland, J.M. Autophagy in female fertility: A role in oxidative stress and aging. Antioxid. Redox Signal. 2020, 32, 550-568. [CrossRef] [PubMed]

13. Zhu, Y.; Yin, Q.; Wei, D.; Yang, Z.; Du, Y.; Ma, Y. Autophagy in male reproduction. Syst. Biol. Reprod. Med. 2019, 65, 265-272. [CrossRef] [PubMed]

14. Choi, J.; Jo, M.; Lee, E.; Oh, Y.K.; Choi, D. The role of autophagy in human endometrium. Biol. Reprod. 2012, 86, 70. [CrossRef] [PubMed]

15. Yang, S.; Wang, H.; Li, D.; Li, M. Role of endometrial autophagy in physiological and pathophysiological processes. J. Cancer 2019, 10, 3459-3471. [CrossRef] [PubMed]

16. Su, Y.; Zhang, J.J.; He, J.L.; Liu, X.Q.; Chen, X.M.; Ding, Y.B.; Tong, C.; Peng, C.; Geng, Y.Q.; Wang, Y.X.; et al. Endometrial autophagy is essential for embryo implantation during early pregnancy. J. Mol. Med. 2020, 98, 555-567. [CrossRef]

17. Lee, J.E.; Oh, H.A.; Song, H.; Jun, J.H.; Roh, C.R.; Xie, H.; Dey, S.K.; Lim, H.J. Autophagy regulates embryonic survival during delayed implantation. Endocrinology 2011, 152, 2067-2075. [CrossRef] [PubMed]

18. Kim, S.M.; Kim, J.S. A review of mechanisms of implantation. Dev. Reprod. 2017, 21, 351-359. [CrossRef]

19. Miravet-Valenciano, J.A.; Rincon-Bertolin, A.; Vilella, F.; Simon, C. Understanding and improving endometrial receptivity. Curr. Opin. Obstet. Gynecol. 2015, 27, 187-192. [CrossRef]

20. Valdes, C.T.; Schutt, A.; Simon, C. Implantation failure of endometrial origin: It is not pathology, but our failure to synchronize the developing embryo with a receptive endometrium. Fertil. Steril. 2017, 108, 15-18. [CrossRef]

21. Fujiwara, H.; Ono, M.; Sato, Y.; Imakawa, K.; Iizuka, T.; Kagami, K.; Fujiwara, T.; Horie, A.; Tani, H.; Hattori, A.; et al. Promoting roles of embryonic signals in embryo implantation and placentation in cooperation with endocrine and immune systems. Int. J. Mol. Sci. 2020, 21, 1885. [CrossRef]

22. Karizbodagh, M.P.; Rashidi, B.; Sahebkar, A.; Masoudifar, A.; Mirzaei, H. Implantation window and angiogenesis. J. Cell. Biochem. 2017, 118, 4141-4151. [CrossRef]

23. Davidson, L.M.; Coward, K. Molecular mechanisms of membrane interaction at implantation. Birth Defects Res. Part C Embryo Today 2016, 108, 19-32. [CrossRef]

24. Ruiz, A.; Rockfield, S.; Taran, N.; Haller, E.; Engelman, R.W.; Flores, I.; Panina-Bordignon, P.; Nanjundan, M. Effect of hydroxychloroquine and characterization of autophagy in a mouse model of endometriosis. Cell Death Dis. 2016, 7, e2059. [CrossRef]

25. Choi, J.; Jo, M.; Lee, E.; Kim, H.J.; Choi, D. Differential induction of autophagy by mtor is associated with abnormal apoptosis in ovarian endometriotic cysts. Mol. Hum. Reprod. 2014, 20, 309-317. [CrossRef] [PubMed]

26. Noh, S.; Go, A.; Kim, D.B.; Park, M.; Jeon, H.W.; Kim, B. Role of antioxidant natural products in management of infertility: A review of their medicinal potential. Antioxidants 2020, 9, 957. [CrossRef] [PubMed]

27. Jaradat, N.; Zaid, A.N. Herbal remedies used for the treatment of infertility in males and females by traditional healers in the rural areas of the west bank/palestine. BMC Complement. Altern. Med. 2019, 19, 194. [CrossRef] [PubMed] 
28. Lee, J.W.; Hyun, M.K.; Kim, H.J.; Kim, D.I. Acupuncture and herbal medicine for female infertility: An overview of systematic reviews. Integr. Med. Res. 2021, 10, 100694. [CrossRef]

29. Deng, S.; Shanmugam, M.K.; Kumar, A.P.; Yap, C.T.; Sethi, G.; Bishayee, A. Targeting autophagy using natural compounds for cancer prevention and therapy. Cancer 2019, 125, 1228-1246. [CrossRef]

30. Raj, S.D.; Fann, D.Y.; Wong, E.; Kennedy, B.K. Natural products as geroprotectors: An autophagy perspective. Med. Res. Rev. 2021, 41,3118-3155. [CrossRef]

31. Kim, J.H.; Kismali, G.; Gupta, S.C. Natural products for the prevention and treatment of chronic inflammatory diseases: Integrating traditional medicine into modern chronic diseases care. Evid.-Based Complement. Altern. Med. 2018, 2018, 9837863. [CrossRef]

32. Zhang, A.; Sun, H.; Wang, X. Recent advances in natural products from plants for treatment of liver diseases. Eur. J. Med. Chem. 2013, 63, 570-577. [CrossRef]

33. Bui, T.T.; Nguyen, T.H. Natural product for the treatment of alzheimer's disease. J. Basic Clin. Physiol. Pharmacol. 2017, $28,413-423$. [CrossRef] [PubMed]

34. Li, J.; Zhang, D.; Wiersma, M.; Brundel, B.J.J.M. Role of autophagy in proteostasis: Friend and foe in cardiac diseases. Cells 2018, 7, 279. [CrossRef] [PubMed]

35. Levine, B.; Mizushima, N.; Virgin, H.W. Autophagy in immunity and inflammation. Nature 2011, 469, 323. [CrossRef]

36. Djajadikerta, A.; Swati, K.; Pavel, M.; Prestil, R.; Ryan, L.; Rubinsztein, D.C. Autophagy induction as a therapeutic strategy for neurodegenerative diseases. J. Mol. Biol. 2020, 432, 2799-2821. [CrossRef] [PubMed]

37. Kovács, A.L.; Reith, A.; Seglen, P.O. Accumulation of autophagosomes after inhibition of hepatocytic protein degradation by vinblastine, leupeptin or a lysosomotropic amine. Exp. Cell Res. 1982, 137, 191-201. [CrossRef]

38. Gonzalez, A.; Hall, M.N.; Lin, S.C.; Hardie, D.G. Ampk and tor: The yin and yang of cellular nutrient sensing and growth control. Cell Metab. 2020, 31, 472-492. [CrossRef]

39. Kim, J.; Kundu, M.; Viollet, B.; Guan, K.L. Ampk and mtor regulate autophagy through direct phosphorylation of ulk1. Nat. Cell Biol. 2011, 13, 132-141. [CrossRef]

40. Hindupur, S.K.; Gonzalez, A.; Hall, M.N. The opposing actions of target of rapamycin and amp-activated protein kinase in cell growth control. Cold Spring Harb. Perspect. Biol. 2015, 7, a019141. [CrossRef]

41. Mizushima, N.; Komatsu, M. Autophagy: Renovation of cells and tissues. Cell 2011, 147, 728-741. [CrossRef]

42. Filomeni, G.; De Zio, D.; Cecconi, F. Oxidative stress and autophagy: The clash between damage and metabolic needs. Cell Death Differ. 2015, 22, 377-388. [CrossRef]

43. Cao, W.; Li, J.; Yang, K.; Cao, D. An overview of autophagy: Mechanism, regulation and research progress. Bull. Cancer 2021, 108, 304-322. [CrossRef] [PubMed]

44. Shackelford, D.B.; Shaw, R.J. The lkb1-ampk pathway: Metabolism and growth control in tumour suppression. Nat. Rev. Cancer 2009, 9, 563-575. [CrossRef] [PubMed]

45. Liang, J.; Shao, S.H.; Xu, Z.X.; Hennessy, B.; Ding, Z.; Larrea, M.; Kondo, S.; Dumont, D.J.; Gutterman, J.U.; Walker, C.L.; et al. The energy sensing lkb1-ampk pathway regulates p27(kip1) phosphorylation mediating the decision to enter autophagy or apoptosis. Nat. Cell Biol. 2007, 9, 218-224. [CrossRef]

46. Zhao, Y.; Hu, X.; Liu, Y.; Dong, S.; Wen, Z.; He, W.; Zhang, S.; Huang, Q.; Shi, M. Ros signaling under metabolic stress: Cross-talk between ampk and akt pathway. Mol. Cancer 2017, 16, 79. [CrossRef]

47. Lamb, C.; Yoshimori, T.; Tooze, S. The autophagosome: Origins unknown, biogenesis complex. Nat. Rev. Mol. Cell Biol. 2013, 14, 759-774. [CrossRef] [PubMed]

48. Russell, R.C.; Tina, Y.; Yuan, H.; Park, H.W.; Chang, Y.Y.; Kim, J.; Kim, H.; Neufeld, T.P.; Dillin, A.; Guan, K.L. Lk1 induces autophagy by phosphorylating beclin-1 and activating vps34 lipid kinase. Nat. Cell Biol. 2013, 15, 741-750. [CrossRef] [PubMed]

49. Mizushima, N.; Yoshimori, T.; Ohsumi, Y. The role of atg proteins in autophagosome formation. Annu. Rev. Cell Dev. Biol. 2011, 27, 107-132. [CrossRef] [PubMed]

50. Klionsky, J.D. The molecular machinery of autophagy: Unanswered questions. J. Cell Sci. 2005, 118, 7-18. [CrossRef]

51. Fujita, N.; Hayashi-Nishino, M.; Fukumoto, H.; Omori, H.; Yamamoto, A.; Noda, T.; Yoshimori, T. An atg4b mutant hampers the lipidation of lc3 paralogues and causes defects in autophagosome closure. Mol. Biol. Cell 2008, 19, 4651-4659. [CrossRef]

52. Weidberg, H.; Shpilka, T.; Shvets, E.; Abada, A.; Shimron, F.; Elazar, Z. Lc3 and gate-16 n termini mediate membrane fusion processes required for autophagosome biogenesis. Dev. Cell 2011, 20, 444-454. [CrossRef]

53. Baeken, M.W.; Weckmann, K.; Diefenthäler, P.; Schulte, J.; Yusifli, K.; Moosmann, B.; Behl, C.; Hajieva, P. Novel insights into the cellular localization and regulation of the autophagosomal proteins lc3a, lc3b and lc3c. Cells Tissues Organs 2020, $18,2315$. [CrossRef]

54. Ichimura, Y.; Kirisako, T.; Takao, T.; Satomi, Y.; Shimonishi, Y.; Ishihara, N.; Mizushima, N.; Tanida, I.; Kominami, E.; Ohsumi, M.; et al. A ubiquitin-like system mediates protein lipidation. Nature 2000, 408, 488-492. [CrossRef]

55. Kabeya, Y.; Mizushima, N.; Yamamoto, A.; Oshitani-Okamoto, S.; Ohsumi, Y.; Yoshimori, T. Lc3, gabarap and gate16 localize to autophagosomal membrane depending on form-ii formation. J. Cell Sci. 2004, 117, 2805-2812. [CrossRef]

56. Tanida, I.; Minematsu-Ikeguchi, N.; Ueno, T.; Kominami, E. Lysosomal turnover, but not a cellular level, of endogenous lc3 is a marker for autophagy. Autophagy 2005, 1, 84-91. [CrossRef]

57. Yim, W.W.; Mizushima, N. Lysosome biology in autophagy. Cell Discov. 2020, 6, 6. [CrossRef] [PubMed] 
58. Pyo, J.O.; Nah, J.; Jung, Y.K. Molecules and their functions in autophagy. Exp. Mol. Med. 2012, 44, 73-80. [CrossRef] [PubMed]

59. Kumar, S.; Sanchez-Alvarez, M.; Lolo, F.N.; Trionfetti, F.; Strippoli, R.; Cordani, M. Autophagy and the lysosomal system in cancer. Cells 2021, 10, 2752. [CrossRef]

60. Settembre, C.; Di Malta, C.; Polito, V.A.; Garcia Arencibia, M.; Vetrini, F.; Erdin, S.; Erdin, S.U.; Huynh, T.; Medina, D.; Colella, P.; et al. Tfeb links autophagy to lysosomal biogenesis. Science 2011, 332, 1429-1433. [CrossRef] [PubMed]

61. Astanina, E.; Bussolino, F.; Doronzo, G. Multifaceted activities of transcription factor eb in cancer onset and progression. Mol. Oncol. 2021, 15, 327-346. [CrossRef]

62. Xu, Y.; Ren, J.; He, X.; Chen, H.; Wei, T.; Feng, W. Ywha/14-3-3 proteins recognize phosphorylated tfeb by a noncanonical mode for controlling tfeb cytoplasmic localization. Autophagy 2019, 15, 1017-1030. [CrossRef]

63. Roczniak-Ferguson, A.; Petit, C.S.; Froehlich, F.; Qian, S.; Ky, J.; Angarola, B.; Walther, T.C.; Ferguson, S.M. The transcription factor tfeb links mtorc1 signaling to transcriptional control of lysosome homeostasis. Sci. Signal. 2012, 5, ra42. [CrossRef]

64. Palmieri, M.; Pal, R.; Nelvagal, H.R.; Lotfi, P.; Stinnett, G.R.; Seymour, M.L.; Chaudhury, A.; Bajaj, L.; Bondar, V.V.; Bremner, L.; et al. Mtorc1-independent tfeb activation via akt inhibition promotes cellular clearance in neurodegenerative storage diseases. Nat. Commun. 2017, 8, 14338. [CrossRef]

65. Parr, C.; Carzaniga, R.; Gentleman, S.M.; Van Leuven, F.; Walter, J.; Sastre, M. Glycogen synthase kinase 3 inhibition promotes lysosomal biogenesis and autophagic degradation of the amyloid-beta precursor protein. Mol. Cell. Biol. 2012, 32, $4410-4418$. [CrossRef]

66. Pena-Llopis, S.; Vega-Rubin-de-Celis, S.; Schwartz, J.C.; Wolff, N.C.; Tran, T.A.; Zou, L.; Xie, X.J.; Corey, D.R.; Brugarolas, J. Regulation of tfeb and v-atpases by mtorc1. EMBO J. 2011, 30, 3242-3258. [CrossRef] [PubMed]

67. Ferron, M.; Settembre, C.; Shimazu, J.; Lacombe, J.; Kato, S.; Rawlings, D.J.; Ballabio, A.; Karsenty, G. A rankl-pkcbeta-tfeb signaling cascade is necessary for lysosomal biogenesis in osteoclasts. Genes Dev. 2013, 27, 955-969. [CrossRef] [PubMed]

68. Zhang, W.; Li, X.; Wang, S.; Chen, Y.; Liu, H. Regulation of tfeb activity and its potential as a therapeutic target against kidney diseases. Cell Death Discov. 2020, 6, 32. [CrossRef] [PubMed]

69. Song, J.X.; Malampati, S.; Zeng, Y.; Durairajan, S.S.K.; Yang, C.B.; Tong, B.C.; Iyaswamy, A.; Shang, W.B.; Sreenivasmurthy, S.G.; $\mathrm{Zhu}, \mathrm{Z}$; ; et al. A small molecule transcription factor eb activator ameliorates beta-amyloid precursor protein and tau pathology in alzheimer's disease models. Aging Cell 2020, 19, e13069. [CrossRef]

70. Cha, J.; Sun, X.; Dey, S.K. Mechanisms of implantation: Strategies for successful pregnancy. Nat. Med. 2012, 18, 1754-1767. [CrossRef] [PubMed]

71. Ochoa-Bernal, M.A.; Fazleabas, A.T. Physiologic events of embryo implantation and decidualization in human and non-human primates. Int. J. Mol. Sci. 2020, 21, 1973. [CrossRef]

72. von Grothusen, C.; Lalitkumar, S.; Boggavarapu, N.R.; Gemzell-Danielsson, K.; Lalitkumar, P.G. Recent advances in understanding endometrial receptivity: Molecular basis and clinical applications. Am. J. Reprod. Immunol. 2014, 72, 148-157. [CrossRef] [PubMed]

73. Ng, S.W.; Norwitz, G.; Pavlicev, M.; Tilburgs, T.; Simón, C.; Norwitz, E.R. Endometrial decidualization: The primary driver of pregnancy health. Int. J. Mol. Sci. 2020, 21, 4092. [CrossRef]

74. Singh, M.; Chaudhry, P.; Asselin, E. Bridging endometrial receptivity and implantation: Network of hormones, cytokines, and growth factors. Endocrinology 2011, 210, 5-14. [CrossRef] [PubMed]

75. Dey, S.K.; Lim, H.; Das, S.K.; Reese, J.; Paria, B.C.; Daikoku, T.; Wang, H. Molecular cues to implantation. Endocr. Rev. 2004, 25, 341-373. [CrossRef]

76. Charnock-Jones, D.S.; Sharkey, A.; Fenwick, P.; Smith, S.K. Leukaemia inhibitory factor mrna concentration peaks in human endometrium at the time of implantation and the blastocyst contains mrna for the receptor at this time. J. Reprod. Fertil. 1994, 101, 421-426. [CrossRef] [PubMed]

77. Tabibzadeh, S.; Kong, Q.; Babaknia, A.; May, L.T. Progressive rise in the expression of interleukin-6 in human endometrium during menstrual cycle is initiated during the implantation window. Hum. Reprod. 1995, 10, 2793-2799. [CrossRef]

78. Norwitz, E.R.; Fisher, D.S.; Schust, J. Implantation and the survival of early pregnancy. N. Engl. J. Med. 2001, 345, 1400-1408. [CrossRef]

79. Binder, N.K.; Evans, J.; Gardner, D.K.; Salamonsen, L.A.; Hannan, N.J. Endometrial signals improve embryo outcome: Functional role of vascular endothelial growth factor isoforms on embryo development and implantation in mice. Hum. Reprod. 2014, 29, 2278-2286. [CrossRef]

80. Yang, J.H.; Chen, C.D.; Chou, C.H.; Wen, W.F.; Tsao, P.N.; Lee, H.; Chen, S.U. Intentional endometrial injury increases embryo implantation potentials through enhanced endometrial angiogenesis. Biol. Reprod. 2018, 100, 381-389. [CrossRef]

81. Shaulov, T.; Sierra, S.; Sylvestre, C. Recurrent implantation failure in ivf: A canadian fertility and andrology society clinical practice guideline. Reprod. Biomed. Online 2020, 41, 819-833. [CrossRef]

82. Busnelli, A.; Somigliana, E.; Cirillo, F.; Baggiani, A.; Levi-Setti, P.E. Efficacy of therapies and interventions for repeated embryo implantation failure: A systematic review and meta-analysis. Sci. Rep. 2021, 11, 1747. [CrossRef]

83. Maleki-Hajiagha, A.; Razavi, M.; Rouholamin, S.; Rezaeinejad, M.; Maroufizadeh, S.; Sepidarkish, M. Intrauterine infusion of autologous platelet-rich plasma in women undergoing assisted reproduction: A systematic review and meta-analysis. J. Reprod. Immunol. 2020, 137, 103078. [CrossRef]

84. Cecchino, G.N.; Garcia-Velasco, J.A. Endometrioma, fertility, and assisted reproductive treatments: Connecting the dots. Curr. Opin. Obstet. Gynecol. 2018, 30, 223-228. [CrossRef] 
85. Konrad, L.; Kortum, J.; Nabham, R.; Gronbach, J.; Dietze, R.; Oehmke, F.; Berkes, E.; Tinneberg, H.R. Composition of the stroma in the human endometrium and endometriosis. Reprod. Sci. 2018, 25, 1106-1115. [CrossRef] [PubMed]

86. Amălinei, C.; Păvăleanu, I.; Grigoraş, A.; Căruntu, I.D.; Giuşcă, S.E.; Avădănei, E.R.; Lozneanu, L.; Balan, R.A. The endometrial regeneration frontiers: From mechanisms to applications in regenerative medicine. Rom. J. Morphol. Embryol. $2018,59,407-425$.

87. Valentijn, A.J.; Palial, K.; Al-Lamee, H.; Tempest, N.; Drury, J.; Von Zglinicki, T.; Saretzki, G.; Murray, P.; Gargett, C.E.; Hapangama, D.K. Ssea-1 isolates human endometrial basal glandular epithelial cells: Phenotypic and functional characterization and implications in the pathogenesis of endometriosis. Hum. Reprod. 2013, 28, 2695-2708. [CrossRef] [PubMed]

88. Jamali, N.; Zal, F.; Mostafavi-Pour, Z.; Samare-Najaf, M.; Poordast, T.; Dehghanian, A. Ameliorative effects of quercetin and metformin and their combination against experimental endometriosis in rats. Reprod. Sci. 2021, 28, 683-692. [CrossRef] [PubMed]

89. Yin, B.; Liu, X.; Guo, S.W. Caloric restriction dramatically stalls lesion growth in mice with induced endometriosis. Reprod. Sci. 2018, 25, 1024-1036. [CrossRef]

90. Matsuzaki, S.; Pouly, J.L.; Canis, M. In vitro and in vivo effects of mk2206 and chloroquine combination therapy on endometriosis: Autophagy may be required for regrowth of endometriosis. Br. J. Pharmacol. 2018, 175, 1637-1653. [CrossRef]

91. Zhan, L.; Li, J.; Wei, B. Autophagy in endometriosis: Friend or foe? Biochem. Biophys. Res. Commun. 2018, 495, 60-63. [CrossRef]

92. Rhee, J.S.; Saben, J.L.; Mayer, A.L.; Schulte, M.B.; Asghar, Z.; Stephens, C.; Chi, M.M.; Moley, K.H. Diet-induced obesity impairs endometrial stromal cell decidualization: A potential role for impaired autophagy. Hum. Reprod. 2016, 31, 1315-1326. [CrossRef]

93. Chen, Q.; Gao, R.; Geng, Y.; Chen, X.; Liu, X.; Zhang, L.; Mu, X.; Ding, Y.; Wang, Y.; He, J. Decreased autophagy was implicated in the decreased apoptosis during decidualization in early pregnant mice. J. Mol. Histol. 2018, 49, 589-597. [CrossRef]

94. Fimia, G.M.; Stoykova, A.; Romagnoli, A.; Giunta, L.; Di Bartolomeo, S.; Nardacci, R.; Corazzari, M.; Fuoco, C.; Ucar, A.; Schwartz, P.; et al. Ambra1 regulates autophagy and development of the nervous system. Nature 2007, 447, 1121-1125. [CrossRef]

95. Gan, B.; Peng, X.; Nagy, T.; Alcaraz, A.; Gu, H.; Guan, J.L. Role of fip200 in cardiac and liver development and its regulation of tnfalpha and tsc-mtor signaling pathways. J. Cell Biol. 2006, 175, 121-133. [CrossRef] [PubMed]

96. Yue, Z.; Jin, S.; Yang, C.; Levine, A.J.; Heintz, N. Beclin 1, an autophagy gene essential for early embryonic development, is a haploinsufficient tumor suppressor. Proc. Natl. Acad. Sci. USA 2003, 100, 15077-15082. [CrossRef]

97. Qu, X.; Yu, J.; Bhagat, G.; Furuya, N.; Hibshoosh, H.; Troxel, A.; Rosen, J.; Eskelinen, E.L.; Mizushima, N.; Ohsumi, Y.; et al. Promotion of tumorigenesis by heterozygous disruption of the beclin 1 autophagy gene. J. Clin. Investig. 2003, 112, 1809-1820. [CrossRef] [PubMed]

98. Oestreich, A.K.; Chadchan, S.; Medvedeva, A.; Lydon, J.P.; Jungheim, E.S.; Moley, K.H.; Kommagani, R. The autophagy protein, fip200 (rb1cc1) mediates progesterone responses governing uterine receptivity and decidualization. Biol. Reprod. 2020, 102, 843-851. [CrossRef] [PubMed]

99. Oestreich, A.K.; Chadchan, S.B.; Popli, P.; Medvedeva, A.; Rowen, M.N.; Stephens, C.S.; Xu, R.; Lydon, J.P.; Demayo, F.J.; Jungheim, E.S.; et al. The autophagy gene atg1611 is necessary for endometrial decidualization. Endocrinology 2020, 161, bqz039. [CrossRef] [PubMed]

100. Yang, D.; Liu, A.; Zhang, Y.; Nan, S.; Yin, R.; Lei, Q.; Zhu, H.; Chen, J.; Han, L.; Ding, M.; et al. Essential role of crim1 on endometrial receptivity in goat. Int. J. Mol. Sci. 2021, 22, 5323. [CrossRef]

101. Zhang, Y.; Gao, R.; Zhang, L.; Geng, Y.; Chen, Q.; Chen, X.; Liu, X.; Mu, X.; Ding, Y.; Wang, Y.; et al. Ampk/mtor downregulated autophagy enhances aberrant endometrial decidualization in folate-deficient pregnant mice. J. Cell. Physiol. 2021, 236, 7376-7389. [CrossRef] [PubMed]

102. Wu, L.; Duan, Q.; Gao, D.; Wang, Y.; Xue, S.; Li, W.; Lei, M. Zearalenone blocks autophagy flow and induces cell apoptosis during embryo implantation in gilts. Toxicol. Sci. 2020, 175, 126-139. [CrossRef]

103. Wang, Z.; Nie, K.; Su, H.; Tang, Y.; Wang, H.; Xu, X.; Dong, H. Berberine improves ovulation and endometrial receptivity in polycystic ovary syndrome. Phytomedicine 2021, 91, 153654. [CrossRef]

104. Ding, W.X.; Ni, H.M.; Gao, W.; Hou, Y.F.; Melan, M.A.; Chen, X.; Stolz, D.B.; Shao, Z.M.; Yin, X.M. Differential effects of endoplasmic reticulum stress-induced autophagy on cell survival. J. Biol. Chem. 2007, 282, 4702-4710. [CrossRef] [PubMed]

105. Zhang, L.J.; Chen, B.; Feng, X.L.; Ma, H.G.; Sun, L.L.; Feng, Y.M.; Liang, G.J.; Cheng, S.F.; Li, L.; Shen, W. Exposure to brefeldin a promotes initiation of meiosis in murine female germ cells. Reprod. Fertil. Dev. 2015, 2, 294-303. [CrossRef]

106. Porowska, H.; Paszkiewicz-Gadek, A.; Lemancewicz, D.; Bielawski, T.; Wo Czynski, S. Effect of brefeldin a on membrane localization of muc1 mucin and adhesive properties of cancer cells. Neoplasma 2008, 55, 305-311. [PubMed]

107. Zhou, L.; Gao, W.; Wang, K.; Huang, Z.; Zhang, L.; Zhang, Z.; Zhou, J.; Nice, E.C.; Huang, C. Brefeldin a inhibits colorectal cancer growth by triggering bip/akt-regulated autophagy. FASEB J. 2019, 33, 5520-5534. [CrossRef]

108. Chien, Y.J.; Chang, C.Y.; Wu, M.Y.; Chen, C.H.; Horng, Y.S.; Wu, H.C. Effects of curcumin on glycemic control and lipid profile in polycystic ovary syndrome: Systematic review with meta-analysis and trial sequential analysis. Nutrients 2021, 13, 684. [CrossRef]

109. Yan, Z.; Dai, Y.; Fu, H.; Zheng, Y.; Bao, D.; Yin, Y.; Chen, Q.; Nie, X.; Hao, Q.; Hou, D.; et al. Curcumin exerts a protective effect against premature ovarian failure in mice. J. Mol. Endocrinol. 2018, 60, 261-271. [CrossRef]

110. Melekoglu, R.; Ciftci, O.; Eraslan, S.; Alan, S.; Basak, N. The protective effects of glycyrrhetinic acid and chrysin against ischemia-reperfusion injury in rat ovaries. Biomed. Res. Int. 2018, 2018, 5421308. [CrossRef]

111. Mihanfar, A.; Nouri, M.; Roshangar, L.; Khadem-Ansari, M.H. Ameliorative effects of fisetin in letrozole-induced rat model of polycystic ovary syndrome. J. Steroid Biochem. Mol. Biol. 2021, 213, 105954. [CrossRef] 
112. Sanchez-Perez, Y.; Morales-Barcenas, R.; Garcia-Cuellar, C.M.; Lopez-Marure, R.; Calderon-Oliver, M.; Pedraza-Chaverri, J.; Chirino, Y.I. The alpha-mangostin prevention on cisplatin-induced apoptotic death in llc-pk1 cells is associated to an inhibition of ros production and p53 induction. Chem. Biol. Interact. 2010, 188, 144-150. [CrossRef]

113. Zhou, J.; Tan, Y.; Wang, X.; Zhu, M. Paeoniflorin attenuates dhea-induced polycystic ovary syndrome via inactivation of tgf-beta1/smads signaling pathway in vivo. Aging 2021, 13, 7084-7095. [CrossRef] [PubMed]

114. Wen, J.; Xu, B.; Sun, Y.; Lian, M.; Li, Y.; Lin, Y.; Chen, D.; Diao, Y.; Almoiliqy, M.; Wang, L. Paeoniflorin protects against intestinal ischemia/reperfusion by activating lkb1/ampk and promoting autophagy. Pharmacol. Res. 2019, 146, 104308. [CrossRef] [PubMed]

115. Dou, X.; Sun, Y.; Li, J.; Zhang, J.; Hao, D.; Liu, W.; Wu, R.; Kong, F.; Peng, X.; Li, J. Short-term rapamycin treatment increases ovarian lifespan in young and middle-aged female mice. Aging Cell 2017, 16, 825-836. [CrossRef] [PubMed]

116. Lee, E.; Min, S.H.; Song, B.S.; Yeon, J.Y.; Kim, J.W.; Bae, J.H.; Park, S.Y.; Lee, Y.H.; Kim, S.U.; Lee, D.S.; et al. Exogenous gamma-tocotrienol promotes preimplantation development and improves the quality of porcine embryos. Reprod. Fertil. Dev. 2015, 27, 481-490. [CrossRef] [PubMed]

117. Zhou, J. The hypothetical molecular pathways of ursolic acid to attenuate the premature ovarian failure in human. Med. Hypotheses 2021, 153, 110636. [CrossRef] [PubMed]

118. Shatrova, A.N.; Burova, E.B.; Kharchenko, M.V.; Smirnova, I.S.; Lyublinskaya, O.G.; Nikolsky, N.N.; Borodkina, A.V. Outcomes of deferoxamine action on h2o2-induced growth inhibition and senescence progression of human endometrial stem cells. Int. J. Mol. Sci. 2021, 22, 6035. [CrossRef]

119. Pullarkat, V.; Meng, Z.; Donohue, C.; Yamamoto, V.N.; Tomassetti, S.; Bhatia, R.; Krishnan, A.; Forman, S.J.; Synold, T.W. Iron chelators induce autophagic cell death in multiple myeloma cells. Leuk. Res. 2014, 38, 988-996. [CrossRef]

120. Park, H.R.; Choi, H.J.; Kim, B.S.; Chung, T.W.; Kim, K.J.; Joo, J.K.; Ryu, D.; Bae, S.J.; Ha, K.T. Paeoniflorin enhances endometrial receptivity through leukemia inhibitory factor. Biomolecules 2021, 11, 439. [CrossRef]

121. Li, J.; Zeng, Z.; Chang, Y.; Li, M.; Wu, Q.; Chen, P.; Liang, X. Suppressive effects of ursolic acid on human endometriotic stromal cells survival. Gynecol. Obstet. Investig. 2020, 85, 72-81. [CrossRef]

122. Radzinsky, V.Y.; Orazov, M.R.; Ivanov, I.I.; Khamoshina, M.B.; Kostin, I.N.; Kavteladze, E.V.; Shustova, V.B. Implantation failures in women with infertility associated endometriosis. Gynecol. Endocrinol. 2019, 35, 27-30. [CrossRef]

123. Orazov, M.R.; Radzinsky, V.Y.; Ivanov, I.I.; Khamoshina, M.B.; Shustova, V.B. Oocyte quality in women with infertility associated endometriosis. Gynecol. Endocrinol. 2019, 35, 24-26. [CrossRef] [PubMed]

124. Fischer, L.; Deppert, W.R.; Pfeifer, D.; Stanzel, S.; Weimer, M.; Hanjalic-Beck, A.; Stein, A.; Strasser, M.; Zahradnik, H.P.; Schaefer W.R. Potential hazards to embryo implantation: A human endometrial in vitro model to identify unwanted antigestagenic actions of chemicals. Toxicol. Appl. Pharmacol. 2012, 260, 232-240. [CrossRef]

125. Devi, Y.S.; DeVine, M.; DeKuiper, J.; Ferguson, S.; Fazleabas, A.T. Inhibition of il-6 signaling pathway by curcumin in uterine decidual cells. PLoS ONE 2015, 10, e0125627. [CrossRef]

126. Li, R.; Zhao, F.; Diao, H.; Xiao, S.; Ye, X. Postweaning dietary genistein exposure advances puberty without significantly affecting early pregnancy in c57bl/6j female mice. Reprod. Toxicol. 2014, 44, 85-92. [CrossRef]

127. Jefferson, W.N.; Padilla-Banks, E.; Goulding, E.H.; Lao, S.P.; Newbold, R.R.; Williams, C.J. Neonatal exposure to genistein disrupts ability of female mouse reproductive tract to support preimplantation embryo development and implantation. Biol. Reprod. 2009, 80, 425-431. [CrossRef]

128. Jefferson, W.N.; Padilla-Banks, E.; Suen, A.A.; Royer, L.J.; Zeldin, S.M.; Arora, R.; Williams, C.J. Uterine patterning, endometrial gland development, and implantation failure in mice exposed neonatally to genistein. Environ. Health Perspect. 2020, $128,37001$. [CrossRef]

129. Shahzad, H.; Giribabu, N.; Karim, K.; Kassim, N.; Muniandy, S.; Kumar, K.E.; Salleh, N. Quercetin interferes with the fluid volume and receptivity development of the uterus in rats during the peri-implantation period. Reprod. Toxicol. 2017, 71, 42-54. [CrossRef] [PubMed]

130. Bolouki, A.; Zal, F.; Mostafavi-Pour, Z.; Bakhtari, A. Protective effects of quercetin on uterine receptivity markers and blastocyst implantation rate in diabetic pregnant mice. Taiwan J. Obstet. Gynecol. 2020, 59, 927-934. [CrossRef] [PubMed]

131. Zheng, Q.; Xu, Y.; Lu, J.; Zhao, J.; Wei, X.; Liu, P. Emodin inhibits migration and invasion of human endometrial stromal cells by facilitating the mesenchymal-epithelial transition through targeting ilk. Reprod. Sci. 2016, 23, 1526-1535. [CrossRef]

132. Zheng, Q.; Wang, J.; Li, W.; Chen, X.; Chen, S.; Chen, L. Emodin reverses the epithelial-mesenchymal transition of human endometrial stromal cells by inhibiting ilk/gsk-3beta pathway. Drug Des. Devel. Ther. 2020, 14, 3663-3672. [CrossRef]

133. Mestre Citrinovitz, A.C.; Langer, L.; Strowitzki, T.; Germeyer, A. Resveratrol enhances decidualization of human endometrial stromal cells. Reproduction 2020, 159, 453-463. [CrossRef]

134. Ochiai, A.; Kuroda, K.; Ozaki, R.; Ikemoto, Y.; Murakami, K.; Muter, J.; Matsumoto, A.; Itakura, A.; Brosens, J.J.; Takeda, S. Resveratrol inhibits decidualization by accelerating downregulation of the crabp2-rar pathway in differentiating human endometrial stromal cells. Cell Death Dis. 2019, 10, 276. [CrossRef]

135. Kuroda, K.; Ochiai, A.; Brosens, J.J. The actions of resveratrol in decidualizing endometrium: Acceleration or inhibition? Biol. Reprod. 2020, 103, 1152-1156. [CrossRef]

136. Velasquez, J.; Wray, A.A. Deferoxamine. In Statpearls; FDA: Treasure Island, FL, USA, 2021. 
137. Ehteshamfar, S.M.; Akhbari, M.; Afshari, J.T.; Seyedi, M.; Nikfar, B.; Shapouri-Moghaddam, A.; Ghanbarzadeh, E.; MomtaziBorojeni, A.A. Anti-inflammatory and immune-modulatory impacts of berberine on activation of autoreactive $t$ cells in autoimmune inflammation. J. Cell Mol. Med. 2020, 24, 13573-13588. [CrossRef]

138. Rauf, A.; Abu-Izneid, T.; Khalil, A.A.; Imran, M.; Shah, Z.A.; Emran, T.B.; Mitra, S.; Khan, Z.; Alhumaydhi, F.A.; Aljohani, A.S.M.; et al. Berberine as a potential anticancer agent: A comprehensive review. Molecules 2021, 26, 7368. [CrossRef]

139. Xing, L.; Zhou, X.; Li, A.H.; Li, H.J.; He, C.X.; Qin, W.; Zhao, D.; Li, P.Q.; Zhu, L.; Cao, H.L. Atheroprotective effects and molecular mechanism of berberine. Front. Mol. Biosci. 2021, 8, 762673. [CrossRef]

140. Tuli, H.S.; Aggarwal, V.; Tuorkey, M.; Aggarwal, D.; Parashar, N.C.; Varol, M.; Savla, R.; Kaur, G.; Mittal, S.; Sak, K. Emodin: A metabolite that exhibits anti-neoplastic activities by modulating multiple oncogenic targets. Toxicol. In Vitro 2021, 73, 105142. [CrossRef]

141. Zheng, Q.; Li, S.; Li, X.; Liu, R. Advances in the study of emodin: An update on pharmacological properties and mechanistic basis. Chin. Med. 2021, 16, 102. [CrossRef]

142. Talebi, A.; Hayati Roodbari, N.; Reza Sameni, H.; Zarbakhsh, S. Impact of coadministration of apigenin and bone marrow stromal cells on damaged ovaries due to chemotherapy in rat: An experimental study. Int. J. Reprod. Biomed. 2020, 18, 551-560. [CrossRef]

143. Soyman, Z.; Kelekci, S.; Sal, V.; Sevket, O.; Bayindir, N.; Uzun, H. Effects of apigenin on experimental ischemia/reperfusion injury in the rat ovary. Balkan Med. J. 2017, 34, 444-449. [CrossRef]

144. Xu, L.; Zaky, M.Y.; Yousuf, W.; Ullah, A.; Abdelbaset, G.R.; Zhang, Y.; Ahmed, O.M.; Liu, S.; Liu, H. The anticancer potential of apigenin via immunoregulation. Curr. Pharm. Des. 2021, 27, 479-489. [CrossRef]

145. Talebi, M.; Talebi, M.; Farkhondeh, T.; Simal-Gandara, J.; Kopustinskiene, D.M.; Bernatoniene, J.; Samarghandian, S. Emerging cellular and molecular mechanisms underlying anticancer indications of chrysin. Cancer Cell Int. 2021, 21, 214. [CrossRef]

146. Mishra, A.; Mishra, P.S.; Bandopadhyay, R.; Khurana, N.; Angelopoulou, E.; Paudel, Y.N.; Piperi, C. Neuroprotective potential of chrysin: Mechanistic insights and therapeutic potential for neurological disorders. Molecules 2021, 26, 6456. [CrossRef]

147. Farooqi, A.A.; Naureen, H.; Zahid, R.; Youssef, L.; Attar, R.; Xu, B. Cancer chemopreventive role of fisetin: Regulation of cell signaling pathways in different cancers. Pharmacol. Res. 2021, 172, 105784. [CrossRef]

148. Ravula, A.R.; Teegala, S.B.; Kalakotla, S.; Pasangulapati, J.P.; Perumal, V.; Boyina, H.K. Fisetin, potential flavonoid with multifarious targets for treating neurological disorders: An updated review. Eur. J. Pharmacol. 2021, 910, 174492. [CrossRef]

149. Nazari-Khanamiri, F.; Ghasemnejad-Berenji, M. Cellular and molecular mechanisms of genistein in prevention and treatment of diseases: An overview. J. Food Biochem. 2021, 45, e13972. [CrossRef]

150. Revuelta, M.P.; Cantabrana, B.; Hidalgo, A. Mechanisms involved in kaempferol-induced relaxation in rat uterine smooth muscle. Life Sci. 2000, 67, 251-259. [CrossRef]

151. Toh, M.F.; Mendonca, E.; Eddie, S.L.; Endsley, M.P.; Lantvit, D.D.; Petukhov, P.A.; Burdette, J.E. Kaempferol exhibits progestogenic effects in ovariectomized rats. J. Steroids Horm. Sci. 2014, 5, 136.

152. Santos, J.M.S.; Monte, A.P.O.; Lins, T.; Barberino, R.S.; Menezes, V.G.; Gouveia, B.B.; Macedo, T.J.S.; Oliveira Junior, J.L.; Donfack N.J.; Matos, M.H.T. Kaempferol can be used as the single antioxidant in the in vitro culture medium, stimulating sheep secondary follicle development through the phosphatidylinositol 3-kinase signaling pathway. Theriogenology 2019, 136, 86-94. [CrossRef] [PubMed]

153. Santos, J.M.S.; Lins, T.; Barberino, R.S.; Menezes, V.G.; Gouveia, B.B.; Matos, M.H.T. Kaempferol promotes primordial follicle activation through the phosphatidylinositol 3-kinase/protein kinase b signaling pathway and reduces DNA fragmentation of sheep preantral follicles cultured in vitro. Mol. Reprod. Dev. 2019, 86, 319-329. [CrossRef] [PubMed]

154. Silva Dos Santos, J.; Goncalves Cirino, J.P.; de Oliveira Carvalho, P.; Ortega, M.M. The pharmacological action of kaempferol in central nervous system diseases: A review. Front. Pharmacol. 2020, 11, 565700. [CrossRef]

155. Sharma, N.; Biswas, S.; Al-Dayan, N.; Alhegaili, A.S.; Sarwat, M. Antioxidant role of kaempferol in prevention of hepatocellular carcinoma. Antioxidants 2021, 10, 1419. [CrossRef]

156. Naseer, Z.; Ahmad, E.; Epikmen, E.T.; Ucan, U.; Boyacioglu, M.; Ipek, E.; Akosy, M. Quercetin supplemented diet improves follicular development, oocyte quality, and reduces ovarian apoptosis in rabbits during summer heat stress. Theriogenology 2017, 96, 136-141. [CrossRef]

157. Merlin, J.P.J.; Rupasinghe, H.P.V.; Dellaire, G.; Murphy, K. Role of dietary antioxidants in p53-mediated cancer chemoprevention and tumor suppression. Oxidative Med. Cell. Longev. 2021, 2021, 9924328. [CrossRef]

158. Di Petrillo, A.; Orru, G.; Fais, A.; Fantini, M.C. Quercetin and its derivates as antiviral potentials: A comprehensive review. Phytother. Res. 2021. [CrossRef]

159. Shih, H.C.; Yang, L.L. Relaxant effect induced by wogonin from scutellaria baicalensis on rat isolated uterine smooth muscle. Pharm. Biol. 2012, 50, 760-765. [CrossRef]

160. Huynh, D.L.; Ngau, T.H.; Nguyen, N.H.; Tran, G.B.; Nguyen, C.T. Potential therapeutic and pharmacological effects of wogonin: An updated review. Mol. Biol. Rep. 2020, 47, 9779-9789. [CrossRef]

161. Sharifi-Rad, J.; Herrera-Bravo, J.; Salazar, L.A.; Shaheen, S.; Abdulmajid Ayatollahi, S.; Kobarfard, F.; Imran, M.; Imran, A.; Custodio, L.; Dolores Lopez, M.; et al. The therapeutic potential of wogonin observed in preclinical studies. Evid.-Based Complement. Altern. Med. 2021, 2021, 9935451. [CrossRef] [PubMed]

162. Dumont, F.J.; Su, Q. Mechanism of action of the immunosuppressant rapamycin. Life Sci. 1996, 58, 373-395. [CrossRef]

163. Li, J.; Kim, S.G.; Blenis, J. Rapamycin: One drug, many effects. Cell Metab. 2014, 19, 373-379. [CrossRef] 
164. Paek, S.M. Recent synthesis and discovery of brefeldin A analogs. Mar. Drugs 2018, 16, 133. [CrossRef]

165. Lu, Y.C.; Chen, H.H.; Ko, C.H.; Lin, Y.R.; Chan, M.H. The mechanism of honokiol-induced and magnolol-induced inhibition on muscle contraction and ca2+ mobilization in rat uterus. Naunyn-Schmiedeberg's Arch. Pharmacol. 2003, 368, 262-269. [CrossRef]

166. Ranaware, A.M.; Banik, K.; Deshpande, V.; Padmavathi, G.; Roy, N.K.; Sethi, G.; Fan, L.; Kumar, A.P.; Kunnumakkara, A.B. Magnolol: A neolignan from the magnolia family for the prevention and treatment of cancer. Int. J. Mol. Sci. 2018, 19, 2362. [CrossRef] [PubMed]

167. Lin, Y.; Li, Y.; Zeng, Y.; Tian, B.; Qu, X.; Yuan, Q.; Song, Y. Pharmacology, toxicity, bioavailability, and formulation of magnolol: An update. Front. Pharmacol. 2021, 12, 632767. [CrossRef] [PubMed]

168. Szalabska-Rapala, K.; Borymska, W.; Kaczmarczyk-Sedlak, I. Effectiveness of magnolol, a lignan from magnolia bark, in diabetes, its complications and comorbidities-a review. Int. J. Mol. Sci. 2021, 22, 10050. [CrossRef] [PubMed]

169. Tang, C.; Liu, Y.; Liu, S.; Yang, C.; Chen, L.; Tang, F.; Wang, F.; Zhan, L.; Deng, H.; Zhou, W.; et al. Curcumin and its analogs as potential epigenetic modulators: Prevention of diabetes and its complications. Pharmacology 2021, 1-13. [CrossRef]

170. Memarzia, A.; Saadat, S.; Behrouz, S.; Boskabady, M.H. Curcuma longa and curcumin affect respiratory and allergic disorders, experimental and clinical evidence: A comprehensive and updated review. Biofactors 2021, 47, 311-350. [CrossRef] [PubMed]

171. Sudhesh Dev, S.; Zainal Abidin, S.A.; Farghadani, R.; Othman, I.; Naidu, R. Receptor tyrosine kinases and their signaling pathways as therapeutic targets of curcumin in cancer. Front. Pharmacol. 2021, 12, 772510. [CrossRef]

172. Hong, G.; Wu, H.; Ma, S.T.; Su, Z. Catechins from oolong tea improve uterine defects by inhibiting stat3 signaling in polycystic ovary syndrome mice. Chin. Med. 2020, 15, 125. [CrossRef] [PubMed]

173. Kamal, D.A.M.; Salamt, N.; Zaid, S.S.M.; Mokhtar, M.H. Beneficial effects of green tea catechins on female reproductive disorders: A review. Molecules 2021, 26, 2675. [CrossRef]

174. Wu, D. Green tea egcg, t-cell function, and t-cell-mediated autoimmune encephalomyelitis. J. Investig. Med. 2016, 64, 1213-1219. [CrossRef] [PubMed]

175. Huang, Y.J.; Wang, K.L.; Chen, H.Y.; Chiang, Y.F.; Hsia, S.M. Protective effects of epigallocatechin gallate (egcg) on endometrial, breast, and ovarian cancers. Biomolecules 2020, 10, 1481. [CrossRef]

176. Fernandes, L.; Cardim-Pires, T.R.; Foguel, D.; Palhano, F.L. Green tea polyphenol epigallocatechin-gallate in amyloid aggregation and neurodegenerative diseases. Front. Neurosci. 2021, 15, 718188. [CrossRef] [PubMed]

177. Liu, M.J.; Sun, A.; Zhao, S.G.; Liu, H.; Ma, S.Y.; Li, M.; Huai, Y.X.; Zhao, H.; Liu, H.B. Resveratrol improves in vitro maturation of oocytes in aged mice and humans. Fertil. Steril. 2018, 109, 900-907. [CrossRef]

178. Wang, X.; Zhu, X.; Liang, X.; Xu, H.; Liao, Y.; Lu, K.; Lu, S. Effects of resveratrol on in vitro maturation of porcine oocytes and subsequent early embryonic development following somatic cell nuclear transfer. Reprod. Domest. Anim. 2019, 54, 1195-1205. [CrossRef] [PubMed]

179. Park, E.J.; Pezzuto, J.M. The pharmacology of resveratrol in animals and humans. Biochim. Biophys. Acta 2015, 1852, 1071-1113. [CrossRef]

180. Berman, A.Y.; Motechin, R.A.; Wiesenfeld, M.Y.; Holz, M.K. The therapeutic potential of resveratrol: A review of clinical trials. Npj Precis. Oncol. 2017, 1, 35. [CrossRef] [PubMed]

181. Xiang, Y.; Zhang, Q.; Wei, S.; Huang, C.; Li, Z.; Gao, Y. Paeoniflorin: A monoterpene glycoside from plants of paeoniaceae family with diverse anticancer activities. J. Pharm. Pharmacol. 2020, 72, 483-495. [CrossRef]

182. Zhou, Y.X.; Gong, X.H.; Zhang, H.; Peng, C. A review on the pharmacokinetics of paeoniflorin and its anti-inflammatory and immunomodulatory effects. Biomed. Pharmacother. 2020, 130, 110505. [CrossRef] [PubMed]

183. Wang, X.L.; Feng, S.T.; Wang, Y.T.; Chen, N.H.; Wang, Z.Z.; Zhang, Y. Paeoniflorin: A neuroprotective monoterpenoid glycoside with promising anti-depressive properties. Phytomedicine 2021, 90, 153669. [CrossRef]

184. Alam, M.; Ali, S.; Ahmed, S.; Elasbali, A.M.; Adnan, M.; Islam, A.; Hassan, M.I.; Yadav, D.K. Therapeutic potential of ursolic acid in cancer and diabetic neuropathy diseases. Int. J. Mol. Sci. 2021, 22, 12162. [CrossRef] [PubMed]

185. Erdmann, J.; Kujacinski, M.; Wicinski, M. Beneficial effects of ursolic acid and its derivatives-focus on potential biochemical mechanisms in cardiovascular conditions. Nutrients 2021, 13, 3900. [CrossRef] [PubMed]

186. Khwaza, V.; Oyedeji, O.O.; Aderibigbe, B.A. Ursolic acid-based derivatives as potential anti-cancer agents: An update. Int. J. Mol. Sci. 2020, 21, 5920. [CrossRef] [PubMed]

187. Ling, M.T.; Luk, S.U.; Al-Ejeh, F.; Khanna, K.K. Tocotrienol as a potential anticancer agent. Carcinogenesis 2012, 33, 233-239. [CrossRef] [PubMed]

188. Ahsan, H.; Ahad, A.; Iqbal, J.; Siddiqui, W.A. Pharmacological potential of tocotrienols: A review. Nutr. Metab. 2014, 11, 52. [CrossRef]

189. Zhang, K.J.; Gu, Q.L.; Yang, K.; Ming, X.J.; Wang, J.X. Anticarcinogenic effects of alpha-mangostin: A review. Planta Med. 2017, 83, 188-202.

190. Yang, A.; Liu, C.; Wu, J.; Kou, X.; Shen, R. A review on alpha-mangostin as a potential multi-target-directed ligand for alzheimer's disease. Eur. J. Pharmacol. 2021, 897, 173950. [CrossRef]

191. Feng, J.; Wang, J.; Zhang, Y.; Zhang, Y.; Jia, L.; Zhang, D.; Zhang, J.; Han, Y.; Luo, S. The efficacy of complementary and alternative medicine in the treatment of female infertility. Evid.-Based Complement. Altern. Med. 2021, 2021, 6634309. [CrossRef] 
192. Cao, H.; Han, M.; Ng, E.H.; Wu, X.; Flower, A.; Lewith, G.; Liu, J.P. Can chinese herbal medicine improve outcomes of in vitro fertilization? A systematic review and meta-analysis of randomized controlled trials. PLoS ONE 2013, 8, e81650. [CrossRef] [PubMed]

193. Guo, J.; Li, D.; Liu, C.; Ji, X.; Li, R.; Du, X. Effects of chinese herbs combined with in vitro fertilization and embryo transplantation on infertility: A clinical randomized controlled trial. J. Tradit. Chin. Med. 2014, 34, 267-273. [CrossRef]

194. Xie, L.; Li, J.; Li, Y.; Wang, B.; Xie, C.; Xia, Q.; Zhang, Z.; Wang, Y. Chinese herbal medicine for assisted reproduction technology: A protocol for a systematic review and meta-analysis. Medicine 2020, 99, e22009. [CrossRef] [PubMed]

195. Cao, X.L.; Song, J.Y.; Zhang, X.X.; Chen, Y.H.; Teng, Y.L.; Liu, H.P.; Deng, T.Y.; Sun, Z.G. Effects of a chinese patent medicine gushen'antai pills on ongoing pregnancy rate of hormone therapy fet cycles: A multi-center, randomized, double-blind, placebocontrolled clinical trial. Front. Endocrinol. 2020, 11, 581719. [CrossRef]

196. Wu, Y.; Zheng, C.; Hu, L.; Li, J. Local immune regulatory effects of bangdeyun on the endometrium of mice with embryo implantation dysfunction during the implantation time. J. Huazhong Univ. Sci. Technol. Med. Sci. 2009, 29, 372-376. [CrossRef]

197. Deng, S.R.; Li, J.; Zhang, Z.Q.; Li, B.; Sheng, L.L.; Zeng, J.W.; Liu, Y.P.; An, S.L.; Wu, Y.X. Ds147 improves pregnancy in mice with embryo implantation dysfunction induced by controlled ovarian stimulation. J. Huazhong Univ. Sci. Technol. Med. Sci. 2013, 33, 573-580. [CrossRef]

198. Li, H.X.; Guo, X.Y.; Xie, Y.; Ge, M.X.; Yuan, Q.L.; Lin, D.W.; Xiong, L.; Deng, W.M.; Zhang, J.Y. Yiqixue buganshen recipe regulates the expression of integrin alphanubeta3 in the endometrium of controlled ovarian hyperstimulation mice. Chin. J. Integr. Med. 2013, 19, 755-760. [CrossRef] [PubMed]

199. Lian, F.; Wu, H.C.; Sun, Z.G.; Guo, Y.; Shi, L.; Xue, M.Y. Effects of liuwei dihuang granule on the outcomes of in vitro fertilization pre-embryo transfer in infertility women with kidney-yin deficiency syndrome and the proteome expressions in the follicular fluid. Chin. J. Integr. Med. 2014, 20, 503-509. [CrossRef]

200. Chen, X.Y.; Chen, J.; Wang, Z.Y.; Yu, X.H.; Wei, B.X.; Wu, X.H. Effects of modified shoutaiwai recipe on integrin beta3 and leukemia-inhibitory factor in endometrium of controlled ovarian hyperstimulation mice during the implantation window. Genet. Mol. Res. 2015, 14, 2970-2977. [CrossRef] [PubMed]

201. Ma, W.W.; Xiao, J.; Song, Y.F.; Ding, J.H.; Tan, X.J.; Song, K.K.; Zhang, M.M. Effect and underlying mechanism of bu-shen-an-tai recipe on ovarian apoptosis in mice with controlled ovarian hyperstimulation implantation dysfunction. J. Huazhong Univ. Sci. Technol. Med. Sci. 2017, 37, 401-406. [CrossRef]

202. Lv, B.Y.; Sun, H.Y.; Li, Q.; Zhang, H.L.; Pan, C.S.; Yan, L.; Fan, J.Y.; Li, D.; Han, J.Y. The ameliorating effects of bushen tiaoxue granules and kunling wan on impaired angiogenesis and endometrial receptivity in rats following controlled ovarian hyperstimulation. Microcirculation 2020, 27, e12581. [CrossRef] [PubMed]

203. Terawaki, K.; Saegusa, Y.; Sekiguchi, K.; Shimizu, T.; Takiyama, M.; Matsumoto, T.; Iizuka, S.; Matsumoto, C.; Motoyama, F. The ameliorating effects of tokishakuyakusan in a rat model of implantation failure involves endometrial gland leukemia inhibitory factor and decidualization. J. Ethnopharmacol. 2021, 265, 113288. [CrossRef]

204. Yuan, L.; Feng, F.; Mao, Z.; Huang, J.; Liu, Y.; Li, Y.; Jiang, R. Effects of erbuzhuyu decoction combined with acupuncture on endometrial receptivity are associated with the expression of mir-494-3p. Evid.-Based Complement. Altern. Med. 2020, $2020,9739672$. [CrossRef]

205. Xin, M.; He, J.; Zhang, Y.; Wu, Y.; Yang, W.; Liang, X.; Yin, X. Chinese herbal decoction of wenshen yangxue formula improved fertility and pregnancy rate in mice through pi3k/akt signaling. J. Cell. Biochem. 2019, 120, 3082-3090. [CrossRef]

206. Song, J.Y.; Gao, D.D.; Cao, X.L.; Xiang, S.; Chen, Y.H.; Teng, Y.L.; Li, X.F.; Liu, H.P.; Wang, F.X.; Zhang, B.; et al. The role of traditional chinese formula ding-kun pill $(\mathrm{dkp})$ in expected poor ovarian response women (poseidon group 4) undergoing in vitro fertilization-embryo transfer: A multicenter, randomized, double-blind, placebo-controlled trial. Front. Endocrinol. 2021, 12, 675997. [CrossRef]

207. Song, J.; Ma, T.; Liang, Y.; Cao, X.; Sun, Z. Efficacy and safety of dingkun pill for female infertility patients with low prognosis undergoing in vitro fertilization-embryo transfer: Study protocol for a multicenter, double-blind, randomized, placebo-controlled trial. Trials 2020, 21, 550. [CrossRef]

208. Liang, J.; Liu, Y.; Shen, M.; Pan, X.; Xu, X.; Xie, B.; Zheng, H. Influence of erbu zhuyu tang on expressions of endometrial autophagy genes-beclin-1 and lc3b in mice with embryo implantation dysfunction. J. Beijing Univ. Tradit. Chin. Med. 2019, 42, 910-915.

209. Ding, J.; Tan, X.; Song, K.; Ma, W.; Xiao, J.; Song, Y.; Zhang, M. Bushen huoxue recipe alleviates implantation loss in mice by enhancing estrogen-progesterone signals and promoting decidual angiogenesis through fgf2 during early pregnancy. Front. Pharmacol. 2018, 9, 437. [CrossRef]

210. Yu, N.; Yang, J.; Yin, T. Extracts from a traditional chinese herbal remedy (zhuyun recipe) improve endometrial receptivity in mice with embryonic implantation dysfunction and ovulation stimulation. J. Ethnopharmacol. 2011, 137, 389-395. [CrossRef]

211. Xin, M.; He, J.; Yang, W.; Yin, X.; Wang, J. Wenshen yangxue decoction improves endometrial receptivity recovery and promotes endometrial angiogenesis in a rat model. Pharm. Biol. 2018, 56, 573-579. [CrossRef]

212. Huang, L.; Wang, L.; Bao, H.; Xu, Y.; Meng, M.; Qiao, M.; Wang, H.; Kong, S. Traditional chinese medicine dingkun pill facilitates uterine receptivity for implantation in mice. Biol. Reprod. 2019, 101, 695-703. [CrossRef] 
213. Choi, H.J.; Joo, B.S.; Park, M.J.; Park, M.J.; Bae, B.; Kim, B.S.; Park, H.R.; Kim, K.J.; Yang, H.J.; Chung, T.W.; et al. Yeosin-san increases female fertility through inducing uterine receptivity and ovarian function. J. Physiol. Pathol. Korean Med. 2019, 33 , 141-150. [CrossRef]

214. Song, Z.; Luo, D.; Wang, Y.; Zheng, Y.; Chen, P.; Xia, X.; He, C.; Yu, W.; Li, P.; Xiao, C.; et al. Neuroprotective effect of danggui shaoyao san via the mitophagy-apoptosis pathway in a rat model of alzheimer's disease. Evid.-Based Complement. Altern. Med. 2021, 2021, 3995958. [CrossRef]

215. Zhang, M.Y.; Chen, H.H.; Tian, J.; Chen, H.J.; Zhu, L.L.; Zhao, P.; Zhang, T. Danggui shaoyao san ameliorates renal fibrosis via regulation of hypoxia and autophagy. Evid.-Based Complement. Altern. Med. 2019, 2019, 2985270. [CrossRef]

216. Kim, S.E.; Lee, J.E.; Han, Y.H.; Lee, S.I.; Kim, D.K.; Park, S.R.; Yu, S.L.; Kang, J. Decursinol from angelica gigas nakai enhances endometrial receptivity during implantation. BMC Complement. Med. Ther. 2020, 20, 36. [CrossRef]

217. Asiedu-Gyekye, I.J.; Borovskaya, T.G.; Poluektova, M.E.; Vychuzhanina, A.V.; Shchemerovsma, Y.A.; Kamalova, S.I.; Grgoreva, V.A.; Amoateng, P.; Kukuia, K.E.; Kwapong, A.A.; et al. Reproductive toxicity of theobroma cacao: Increase in survival index, nongenotoxic, and proimplantation potential. J. Toxicol. 2021, 2021, 6114672. [CrossRef]

218. Belanger, D.; Calder, M.D.; Gianetto-Berruti, A.; Lui, E.M.; Watson, A.J.; Feyles, V. Effects of american ginseng on preimplantation development and pregnancy in mice. Am. J. Chin. Med. 2016, 44, 981-995. [CrossRef]

219. Arlorio, M.; Bottini, C.; Travaglia, F.; Locatelli, M.; Bordiga, M.; Coisson, J.D.; Martelli, A.; Tessitore, L. Protective activity of theobroma cacao 1. Phenolic extract on aml12 and mlp29 liver cells by preventing apoptosis and inducing autophagy. J. Agric. Food Chem. 2009, 57, 10612-10618. [CrossRef] [PubMed]

220. Alvarez-Cilleros, D.; Lopez-Oliva, M.E.; Martin, M.A.; Ramos, S. Cocoa ameliorates renal injury in zucker diabetic fatty rats by preventing oxidative stress, apoptosis and inactivation of autophagy. Food Funct. 2019, 10, 7926-7939. [CrossRef] [PubMed]

221. Kim, S.; Lee, S.I.; Kim, N.; Joo, M.; Lee, K.H.; Lee, M.W.; Jeon, H.J.; Ryu, H.; Kim, J.M.; Sul, J.Y.; et al. Decursin inhibits cell growth and autophagic flux in gastric cancer via suppression of cathepsin c. Am. J. Cancer Res. 2021, 11, 1304-1320. [PubMed]

222. Kim, E.Y.; Choi, H.J.; Chung, T.W.; Choi, J.Y.; Kim, H.S.; Jung, Y.S.; Lee, S.O.; Ha, K.T. Water-extracted perilla frutescens increases endometrial receptivity though leukemia inhibitory factor-dependent expression of integrins. J. Pharmacol. Sci. 2016, 131, 259-266. [CrossRef]

223. Choi, H.J.; Chung, T.W.; Park, M.J.; Jung, Y.S.; Lee, S.O.; Kim, K.J.; Ha, K.T. Water-extracted tubers of cyperus rotundus l. Enhance endometrial receptivity through leukemia inhibitory factor-mediated expression of integrin alphavbeta3 and alphavbeta5. $J$. Ethnopharmacol. 2017, 208, 16-23. [CrossRef] [PubMed]

224. Kim, E.-Y.; Chung, T.-W.; Choi, H.-J.; Ha, K.-T.; Jung, Y.-S.; Lee, S.-O.; Choi, J.-Y.; Kim, H.S.; You, S.; Lee, M.S. Extracts from paeonia lactiflora pallas, rehmannia glutinosa var. Purpurea makino, perilla frutescens var. Acuta kudo may increase the endometrial receptivity through expression of leukemia inhibitory factor and adhesion molecules. J. Tradit. Chin. Med. Sci. $2019,39,25$.

225. Choi, H.J.; Chung, T.W.; Park, M.J.; Lee, K.S.; Yoon, Y.; Kim, H.S.; Lee, J.H.; Kwon, S.M.; Lee, S.O.; Kim, K.J.; et al. Paeonia lactiflora enhances the adhesion of trophoblast to the endometrium via induction of leukemia inhibitory factor expression. PLoS ONE 2016, 11, e0148232.

226. Chen, Y.; Liu, Q.; Shan, Z.; Mi, W.; Zhao, Y.; Li, M.; Wang, B.; Zheng, X.; Feng, W. Catalpol ameliorates podocyte injury by stabilizing cytoskeleton and enhancing autophagy in diabetic nephropathy. Front. Pharmacol. 2019, 10, 1477. [CrossRef]

227. Ren, H.; Wang, D.; Zhang, L.; Kang, X.; Li, Y.; Zhou, X.; Yuan, G. Catalpol induces autophagy and attenuates liver steatosis in $\mathrm{ob} / \mathrm{ob}$ and high-fat diet-induced obese mice. Aging 2019, 11, 9461-9477. [CrossRef] [PubMed]

228. Zhang, Y.; Liu, S.; Feng, Q.; Huang, X.; Wang, X.; Peng, Y.; Zhao, Z.; Liu, Z. Perilaldehyde activates amp-activated protein kinase to suppress the growth of gastric cancer via induction of autophagy. J. Cell. Biochem. 2018, 120, 1716-1725. [CrossRef]

229. Wang, F.; Song, X.; Ma, S.; Liu, C.; Sun, X.; Wang, X.; Liu, Z.; Liang, D.; Yu, Z. The treatment role of cyperus rotundus 1. To triple-negative breast cancer cells. Biosci. Rep. 2019, 39, BSR20190502. [CrossRef]

230. Yang, L.; Liu, S.; Mu, S.; Guo, R.; Zhou, L.; Fu, Q. Paeoniflorin attenuates dexamethasone-induced apoptosis of osteoblast cells and promotes bone formation via regulating akt/mtor/autophagy signaling pathway. Evid.-Based Complement. Altern. Med. 2021, 2021, 6623464. [CrossRef]

231. Cao, B.Y.; Yang, Y.; Luo, W.F.; Mao, C.J.; Han, R.; Sun, X.; Cheng, J.; Liu, C.F. Paeoniflorin, a potent natural compound, protects pc12 cells from mpp+ and acidic damage via autophagic pathway. J. Ethnopharmacol. 2010, 131, 122-129. [CrossRef]

232. Agarwal, A.; Aponte-Mellado, A.; Premkumar, B.J.; Shaman, A.; Gupta, S. The effects of oxidative stress on female reproduction: A review. Reprod. Biol. Endocrinol. 2012, 10, 49. [CrossRef] [PubMed]

233. Khadzhieva, M.B.; Lutcenko, N.N.; Volodin, I.V.; Morozova, K.V.; Salnikova, L.E. Association of oxidative stress-related genes with idiopathic recurrent miscarriage. Free Radic. Res. 2014, 48, 534-541. [CrossRef] [PubMed]

234. Li, J.; Qi, J.; Yao, G.; Zhu, Q.; Li, X.; Xu, R.; Zhu, Z.; Zhao, H.; Wang, Y.; Ding, Y.; et al. Deficiency of sirtuin 1 impedes endometrial decidualization in recurrent implantation failure patients. Front. Cell Dev. Biol. 2021, 9, 598364. [CrossRef] [PubMed]

235. Yao, S.; Wei, W.; Cao, R.; Lu, L.; Liang, S.; Xiong, M.; Zhang, C.; Liang, X.; Ma, Y. Resveratrol alleviates zea-induced decidualization disturbance in human endometrial stromal cells. Ecotoxicol. Environ. Saf. 2021, 207, 111511. [CrossRef] [PubMed]

236. Jeon, S.; Liu, Q.; Cai, H.; Jeong, H.J.; Kim, S.H.; Kim, D.I.; Lee, J.H. Administration of a herbal formulation enhanced blastocyst implantation via ikb activation in mouse endometrium. Chin. Med. 2020, 15, 112. [CrossRef] [PubMed] 
237. Xu, M.; Tian, Y.Z.; Zhu, X.J.; Zhang, X.; Zhu, J.Y.; Gu, C.X.; Chen, Y.; Huang, J.L. Effect of xianziyizhen recipe capsule on pgi2-ppardelta signaling pathway in embryo implantation dysfunction mice. Am. J. Reprod. Immunol. 2015, 73, 545-556. [CrossRef]

238. Koo, J.M.; Yang, M.J.; Kim, B.K.; Yoo, J.E.; Park, J.K.; Yang, H.J.; Joo, J.; Joo, B.S.; Heo, J.D.; Ha, K.T. Acute and repeated toxicological study of anti-inflammatory herbal formula, yeosinsan, in rats. Appl. Sci. 2021, 11, 9325. [CrossRef]

239. Chung, T.W.; Park, M.; Lee, H.; Kim, K.J.; Kim, C.H.; Choi, H.J.; Ha, K.T. Enhancement of endometrial receptivity by cnidium officinale through expressing lif and integrins. Evid.-Based Complement. Altern. Med. 2019, 2019, 7560631. [CrossRef]

240. Guo, Z.; Cao, G.; Yang, H.; Zhou, H.; Li, L.; Cao, Z.; Yu, B.; Kou, J. A combination of four active compounds alleviates cerebral ischemia-reperfusion injury in correlation with inhibition of autophagy and modulation of ampk/mtor and jnk pathways. $J$. Neurosci. Res. 2014, 92, 1295-1306. [CrossRef] [PubMed]

241. Shi, Y.; Gao, Y.; Wang, T.; Wang, X.; He, J.; Xu, J.; Wu, B.; Li, Y. Ginsenoside rg1 alleviates podocyte emt passage by regulating akt/gsk3 beta/beta-catenin pathway by restoring autophagic activity. Evid.-Based Complement. Altern. Med. 2020, 2020, 1903627. [CrossRef]

242. Wang, C.C.; Li, L.; Tang, L.Y.; Leung, P.C. Safety evaluation of commonly used chinese herbal medicines during pregnancy in mice. Hum. Reprod. 2012, 27, 2448-2456. [CrossRef]

243. Dosoky, N.S.; Setzer, W.N. Maternal reproductive toxicity of some essential oils and their constituents. Int. J. Mol. Sci. 2021, 22, 2380. [CrossRef]

244. Oskouei Shirvan, Z.; Etemad, L.; Zafari, R.; Moallem, S.A.; Vahdati-Mashhadian, N.; Hosseinzadeh, H. Teratogenic effect of lippia citriodora leaves aqueous extract in mice. Avicenna J. Phytomed. 2016, 6, 175-180.

245. Li, L.; Tang, L.Y.; Man, G.C.; Yeung, B.H.; Lau, C.B.; Leung, P.C.; Wang, C.C. Potential reproductive toxicity of largehead atractylodes rhizome, the most commonly used chinese medicine for threatened miscarriage. Hum. Reprod. 2011, 26, 3280-3288. [CrossRef] [PubMed]

246. Xu, W.; Xu, L.; Deng, B.; Leng, J.; Tang, N.; Zhao, L.C.; Zhou, H.H.; Zhao, Z.Z.; Yang, Z.J.; Xiao, T.T.; et al. The potential impact of radix paeoniae alba in embryonic development of mice. Phytother. Res. 2017, 31, 1376-1383. [CrossRef] [PubMed]

247. Esimone, C.O.; Akah, P.A.; Nworu, C.S. Efficacy and safety assessment of $\mathrm{t}$. Angelica herbal tonic, a phytomedicinal product popularly used in nigeria. Evid.-Based Complement. Altern. Med. 2011, 2011, 123036. [CrossRef]

248. Lee, J.; Jeong, J.S.; Cho, K.J.; Moon, K.N.; Kim, S.Y.; Han, B.; Kim, Y.S.; Jeong, E.J.; Chung, M.K.; Yu, W.J. Developmental and reproductive toxicity assessment in rats with $\mathrm{kgc}-\mathrm{hj} 3$, korean red ginseng with angelica gigas and deer antlers. J. Ginseng Res. 2019, 43, 242-251. [CrossRef] [PubMed]

249. Shin, S.; Jang, J.Y.; Park, D.; Yon, J.M.; Baek, I.J.; Hwang, B.Y.; Nam, S.Y.; Yun, Y.W.; Kim, K.Y.; Joo, S.S.; et al. Korean red ginseng extract does not cause embryo-fetal death or abnormalities in mice. Birth Defects Res. Part B Dev. Reprod. Toxicol. 2010, 89, 78-85. [CrossRef]

250. Ratno Budiarto, B.; Chan, W.H. Oxidative stresses-mediated apoptotic effects of ginsenoside rb1 on pre- and post-implantation mouse embryos in vitro and in vivo. Environ. Toxicol. 2017, 32, 1990-2003. [CrossRef]

251. Stacchiotti, A.; Corsetti, G. Natural compounds and autophagy: Allies against neurodegeneration. Front. Cell Dev. Biol. 2020, 8, 555409. [CrossRef]

252. Yao, H.; Liu, J.; Xu, S.; Zhu, Z.; Xu, J. The structural modification of natural products for novel drug discovery. Expert Opin. Drug Discov. 2017, 12, 121-140. [CrossRef] [PubMed]

253. Guo, Z.R. The modification of natural products for medical use. Acta Pharm. Sin. B 2017, 7, 119-136. [CrossRef]

254. Agarwal, S.; Maekawa, T. Nano delivery of natural substances as prospective autophagy modulators in glioblastoma. Nanomedicine 2020, 29, 102270. [CrossRef]

255. Meena, J.; Gupta, A.; Ahuja, R.; Singh, M.; Bhaskar, S.; Panda, A.K. Inorganic nanoparticles for natural product delivery: A review. Environ. Chem. Lett. 2020, 18, 2107-2118. [CrossRef] 